\title{
Otomotiv Sektöründe Marka Bağlılığı: Toyota Türkiye Hayran Topluluğu Üzerine Netnografik Bir Araştırma*
}

\author{
Timuçin DALGIÇ**, Muhammet Ali TILLTAY ${ }^{* * *}$
}

ÖZ

Bu çalışmada, Türkiye'de otomotiv sektöründeki marka bağlılığının nasıl oluştuğu irdelenmiştir. Toyota markasının Türkiye hayran sayfası "www.toyotaclubtr.com”, tüketici içgörülerine odaklanan ve çevrimiçi mecraların keşfedilmesinde etkili olan netnografi yöntemi kullanılarak analiz edilmiştir. Araştırma sonucunda Toyota markası kullanıcılarının altı örüntü altında marka bağlılığı oluşturabileceği tespit edilmiștir. Bunlar: (1) Menșe ülke etkisi (2) Markaya özgü nitelikler (3) Uzun süreli kullanım (4) Duygusal bağl1lık (5) Ekonomik faktörler (6) Memnuniyettir. Oluşan örüntüler ve alt boyutları, davranışsal marka bağlılığı ve tutumsal marka bağlılığı açısından değerlendirilmiştir. Türkiye'de otomotiv sektöründe gerçek bir marka bağl1lığının, davranışsal marka bağlılığının olumlu tutumlar ile desteklenmesi sonucu oluşabileceği tespit edilmiştir. Çalışma sonucunda sektöre ve araştırmacılara yönelik olarak tespit edilen öneriler de ayrıca sunulmuştur.

Anahtar Kelimeler: Otomotiv Sektörü, Marka Bağl1lığı, Netnografi

JEL Sinıflandırması: M3, M31

\section{Brand Loyalty in the Automotive Industry: A Netnographic Research on Toyota Fan Community}

\begin{abstract}
In this study it has been examined how brand loyalty in the automotive sector is formed in Turkey. Toyota brand's Turkey fan page "www.toyotaclubtr.com" has been analyzed using the netnography method, which focuses on consumer insights and is influential in the discovery of online medias. In this study, it has been determined that Toyota brand users could create brand loyalty under six patterns. These were: (1) Country of Origin Effect, (2) Brandspecific characteristics, (3) Long-term use, (4) Emotional commitment, (5) Economic factors (6) Satisfaction. Patterns and sub-dimensions were reviewed in terms of behavioral brand loyalty and attitudinal brand loyalty. It has been determined that a real brand loyalty in the automotive sector in Turkey can be formed as a result of supporting behavioral brand loyalty with positive attitudes. As a result of the study, the recommendations identified for the sector and the researchers have also been presented.
\end{abstract}

Keywords: Automotive Sector, Brand Loyalty, Netnography

JEL Classification: M3, M31

Geliş Tarihi / Received: 12.09.2019 Kabul Tarihi / Accepted: 28.11.2019

\footnotetext{
* Bu çalışma Eskişehir Osmangazi Üniversitesi Sosyal Bilimler Enstitüsünde Doç. Dr. Muhammet Ali TİLTAY danışmanlığında Timuçin DALGIÇ tarafından yazılan "Otomotiv sektöründe marka bağlılığı üzerine netnografik bir araştırma: Toyota Türkiye hayran topluluğu örneği" adlı yüksek lisans tezini temel almaktadır.

** Uzman, Eskişehir Osmangazi Üniversitesi, Sosyal Bilimler Enstitüsü, timucindalgic@outlook.com, ORCID: 00000001-5629-9185.

**** Doç. Dr., Eskişehir Osmangazi Üniversitesi, İİBF, İşletme Bölümü, matiltay@gmail.com, ORCID: 0000-00017778-8523.
} 


\section{GİRIŞ}

Günümüzde yaşanan yoğun rekabet koşullarında avantaj elde etmek isteyen markalar için marka bağlılığı yaratmak, gereklilik olmaktan çıkarak zorunluluk haline gelmektedir. Bu durum otomotiv sektörü için de geçerlidir. Teknolojinin etkisiyle benzer özelliklere sahip otomobillerin, yakın fiyatlarla pazardaki bilinçli tüketicilere sunulabilmesi, markaların ötekilerden farklılaşma, müşterilerini elde tutma ve mümkünse markalarına bağlı müşteriler yaratma ihtiyacını doğurmaktadır. $\mathrm{Bu}$ açıdan otomobil gibi çok boyutlu bir ürünün (Vasconcellos, 1997) söz konusu olduğu ve rekabetin yoğun yaşandığ karmaşık bir fenomen olduğu geçmişten günümüze dek irdelenmesine rağmen araştırmacıların ortak bir tanım üzerinde birleşemediklerine istinaden söylenebilecek olan marka bağlılığ kavramının, tüketicilerde nasıl oluştuğunun keşfedilmesi sektör ve araştırmacılardan açısından önem arz etmektedir.

İlgili literatüre bakıldığında otomobil sektöründe marka bağlılığını ele alan sınırlı sayıda ve belli boyutlar üzerine odaklanan çalışmalar olduğu, otomotiv sektöründe marka bağl1lığının bütüncül bir biçimde araştırılmadığı görülmektedir. $\mathrm{Bu}$ araştırmada ise marka bağlılığ kavramının keşfedilmesi gereken, değişken ve karmaşık bir fenomen olduğu bu açıdan bazı tanımlara veya belli boyutlarla ilgili ön kabullere bağlı kalınmaksızın tümevarımsal bir kurguyla irdelenmesi gerektiği düşünülmektedir. $\mathrm{Bu}$ sayede mevcut müşterileri elde tutmanın yeni müşteriler kazanmaktan daha karlı olduğunun hemen herkes tarafından kabul edildiği ve markalarına karşı sadık müşterileri olmayan işletmelerin her açıdan zayıf ve savunmasız görüldüğ̈̈ (Aaker, 2009) günümüzde, otomotiv sektörü açısından nasıl marka bağlılı̆̆ yaratılabileceğinin keşfedilmesi amaçlanmıştır. Teknolojinin etkisiyle markaların benzer özellikte otomobilleri yakın fiyatlarla sunabildiği ve yüksek rekabetin hâkim olduğu pazarda, uzun vadeli ilişkilerin nasıl yaratılabileceğinin keşfedilmesi, inovasyonun rekabetin gücünü belirlediği sektörde (KPMG, 26 Ocak 2018) marka bağlılı̆̆1 yaratabilecek yenilikçi fikirler üretilmesi ve sektöre tavsiyelerde bulunulmasına da olanak sağlayacaktır.

$\mathrm{Bu}$ doğrultuda araştırmanın amacı, otomotiv sektöründe marka bağlılığının nasıl oluştuğunun keşfedilmesidir. Araştırmada incelenmek üzere Toyota Türkiye hayran topluluğunun çevrimiçi sayfası "www.toyotaclubtr.com" seçilmiştir.

Çalışmada, tüketicilerin markalarını tekrar satın alacaklarını, tercih edeceklerini bildirmeleri veya bu ihtimalin varlığına değinmeleri davranışsal marka bağlılığı (Brown, 1952; Cunningham, 1956), bu davranışların nedenleri, bu davranışları organize eden eğilimler, duygusal, arzusal ve bilişsel boyutların oluşturabileceği her türlü olumlu tutum ise tutumsal marka bağlılı̆̆1 (Amine, 1998; Dick ve Basu, 1994; Morgan ve Hunt, 1994) açısından değerlendirilerek otomotiv sektöründe marka bağlılığının nasıl oluştuğu araştırılmıştır. Ayrıca araştırmada marka bağl1lı̆̆ kavramı; duygusal, psikolojik veya farklı çeşitli etkenler sonucu markaya karşı oluşan bağın, diğer pazarlama faaliyetlerini yok sayma davranışı veya tutumuna yol açması ve bu davranış veya tutumun derecesine bağlı olarak oluşturacağ tekrar eden satın alma davranışı veya bir markayı ötekilerden daha sık tercih etme durumu (Jacoby, 1971: 25; Jacoby ve Keyner, 1973; Mellens vd. , 1996: 512; Oliver, 1999: 34; Warrington ve Shim, 2000) olarak tanımlanmıştır.

\section{KAVRAMSAL ÇERÇEVE}

Marka bağlılığının geçmişten günümüze farklı isimler altında çeşitli tanımlarının yapıldığı ve karmaşık bir yapıya sahip olduğu görülmektedir. Marka bağlılı̆̆ 1 ile ilgili literatüre giren ilk çalışmanın 1923 yılında Copeland tarafından yapıldığı söylenebilir (Fournier ve Yao, 1997: 451). O zamandan bu yana yaşanan değişimin marka bağlılı̆̆ kavramını ön plana 
çıkarmasıyla birlikte, kavram ile ilgili yapılan çalışmalar da artmıştır. Özellikle eldeki müşterileri korumanın yeni müşteriler elde etmekten daha karlı ve stratejik olduğunun hemen herkes tarafından kabul edildiği ve teknoloji etkisiyle hem pazar şartlarının hem de tüketim anlayışının tamamen değiştiği günümüzde, marka ve marka bağlılığı kavramları son derece önemli hale gelmiştir.

Mellens vd. (1996: 512) marka bağlılı̆̆ının davranışsal ve tutumsal olmak üzere temel iki boyut etrafında oluştuğunu ifade etmektedir. Marka bağlılığı tanımları da bu iki boyut göz önünde bulundurularak davranışların ve tutumların etkilendiği iki ana gruba ayrılabilir. Nitekim pazarlama literatüründeki marka bağl1lığ tanımlarına bakıldığında, marka bağl1lı̆̆ yapılan ilk çalışmalarda, tekrarlanan satın alma davranışı olarak tanımlanan kavramın (Gustafsson vd. ,2005: 211) günümüze yaklaştıkça markaya karşı oluşan olumlu tutumlara bağlı olarak açıklanmaya başlandığı görülecektir. Günümüzde ise bu iki yaklaşımı bir araya getiren ve marka bağlılığını hem davranışsal hem de tutumsal olarak açıklayan tanımlar sıklıkla kullanılmaktadır. Bu bağlamda marka bağlılı̆̆ının oluşumu ve açıklanma biçimleri üzerinde durulması önem kazanmaktadır.

Marka bağlılığı tanımlarına ve ele alınış biçimlerine bakıldığında ilk zamanlarda davranışsal olarak oluştuğu düşünülen kavram (Brown, 1952; Cunningham, 1956) daha sonra bu davranışların altındaki nedenlerin sorgulanması gerektiğini ve sadece tekrar eden satın alma davranışının marka bağlılığının açıklanmasında yetersiz kaldığını düşünen araştırmacılar tarafından irdelenerek, marka bağlılığ tutumsal açıdan ele alınmaya başlanmıştır. Literatürde kimi kaynaklarda tesadüfi yaklaşım olarak ele alınan ve marka bağlılı̆̆ını davranışsal boyuta bağlayan yaklaşımda, marka bağlılı̆̆ının varlı̆̆ından söz edilebilmesi için bir markayı ötekine tercih etme ve o markayı tekrarlayacak şekilde satın almak yeterlidir. Ancak araştırmacılar gerçek bir marka bağlılığından söz edilebilmesi için markanın devamlı olarak tercih edilmesinin yanı sıra markaya karşı olumlu tutumlar sergilenmesi gerektiğini savunmaktadır (Amine, 1998: 305-306). Bu durumun sebebi bir markanın, mağaza sadakati, ürün çeşitliliğinin darlığ fiyat gibi değişkenler sonucunda tercih ediliyor olabilmesidir. Yine reklam, promosyon, teşvik, indirim gibi geleneksel tutundurma çabalarının da tekrar eden bir satın alma davranışına yol açabileceği (Cunningham, 1956), ancak bunların gerçek bir bağl1lı̆̆ın göstergesi olmayacağı belirtilmektedir.

Marka bağl1lı̆̆ından söz edilebilmesi için sadece olumlu tutumların da yeterli olmayacağı aşikardır. Nitekim literatürde bir markaya karşı olumlu tutumlar sergilenmesine karşın başka markanın tercih edilebildiğinden bahsedilmekte, Dick ve Basu (1994: 100-102) markaya karşı olumlu tutumları olan ancak düşük satın alma davranışı gösteren bu gibi tüketicileri gizli bağlılar olarak adlandırmaktadır. Bu bağlamda günümüzde marka bağlılığını davranışsal boyutunun yanı sıra tutumsal boyutuyla da ele alan Morgan ve Hunt'un (1994) yaklaşımı, geçerli yaklaşımlardan biri olarak değerlendirilebilir. Bu yaklaşıma göre marka bağlıllğ 1 , tüketicinin marka ile arasındaki ilişkiyi önemli görerek bu ilişkiyi sürdürme arzusu olarak tanımlanmaktadır.

Türkçe literatürde marka bağımlılı̆̆1 başlı̆̆ı altında Odabaş1 (1986: 37) tarafindan tanımlanan kavram tüketicinin tercih ettiği markayı her seferinde satın alma eğilimi olarak geçmektedir. Schoenbachler vd. (2004) ise marka bağlılığını sadece tüketicinin tercih ettiği markayı tekrar alması değil aynı zamanda markaya karşı psikolojik ve davranışsal bir eğilim olarak görmektedir.

Zineldin'e (2006: 433) göre arzular, inançlar, tutumlar seti ve bir çeşit ruh hali olarak görülebilecek olan marka bağlılı̆̆ sadece markalara yönelik olarak değil aynı zamanda hizmetlere, mağazalara, ürün sınıflarına ve çeşitli aktivitelere karşı da oluşabilmektedir. Oliver'a (1999: 34) göre marka bağ 11 lı̆ı, yeniden satın alma konusunda derin bir istek duyma veya bir ürün/hizmeti istikrarlı bir şekilde tercih etme, böylece diğer durumsal etki ve pazarlama 
çabalarından etkilenmeyerek aynı markayı tekrar satın almadır. Jacoby (1971: 25) ise marka bağlılığını, bir markayı ötekilerden daha sık tercih etme eğilimi olarak açıklamaktadır.

Literatürde sıklıkla birbirinin yerine kullanılan marka bağlılığı ve marka sadakati kavramlarının belli noktalarda birbirinden ayrıldığını, belli noktalarda ise iç içe geçtiklerini söylemek mümkündür. Marka sadakati belli bir ürün sınıfında markaya karşı olan duygusal ve psikolojik bağlılık olarak tanımlanır ve o ürün sınıfında yalnızca o markaya bağlı kalınmasını ifade eder. Marka bağlılığı ise sadece tüketicinin satın almasını basitleştirir ancak tercih edilen markanın olmaması durumunda, markaya bağlı müşteriler markayı değiştirir ve başka markayı tercih ederken, markaya sadık müşteriler bunu yapmazlar (Warrington ve Shim, 2000). Bir başka açıdan, müşteriler bazı nedenlerden dolayı memnun olmadıkları ürün ve hizmetlere karşı sadık kalabilirler. Tam tersi memnun oldukları ürünü değiştirme yoluna da gidebilirler. Bu noktada birçok araştırmacı ve yazar tarafından eş anlamlı kullanılan bağlılık ve sadakat terimlerinin ayrımı Traylor (1983) tarafından; sadakatin davranışsal bir olgu olduğu, bağl1lı̆̆ın ise duygusal ya da psikolojik bir kavram olduğu şeklinde yapılmıştır (Kabiraj ve Shanmugan, 2011: 289). Bu bağlamda marka sadakati, bir müşterinin markaya bağlılığının derecesi olarak değerlendirilebilir ve bir müşteri tercih ettiği marka, fiyat veya ürün özelliklerinde değişikliğe gittiğinde, o müşterinin başka markaya geçmesinin ne kadar olası olduğunu yansıtır (Aaker, 2009).

$\mathrm{Bu}$ ifadeler göz önüne alındığında marka bağlılığı ve marka sadakati birbiriyle yakından ilişkili ama farklı kavramlar olarak gözükmekle birlikte aynı şeyleri ifade eden kavramlar olarak da kullanılmaktadır. Aralarındaki fark gerçek marka bağlılığı ve sahte marka bağl1lığını ayırt etmek amacıyla kullanılabilir (Sönmez, 2009: 42-43). Bu durumun ayrıca ele alınması gerektiği düşünüldüğünden bu çalışmada, marka bağlılığı ve marka sadakati kavramları; duygusal, psikolojik veya farklı çeşitli etkenler sonucu markaya karşı oluşan bağın, diğer pazarlama faaliyetlerini yok sayma davranışı veya tutumuna yol açması ve bu davranış veya tutumun derecesine bağlı olarak oluşturacağ 1 tekrar eden satın alma davranışı veya bir markayı ötekilerden daha s1k tercih etme durumunu (Jacoby, 1971: 25; Jacoby ve Keyner, 1973; Mellens vd. , 1996: 512; Oliver, 1999: 34; Warrington ve Shim, 2000) ifade edecek şekilde birbirinin yerine kullanılabilecektir.

Türkçe literatürde otomotiv sektörü üzerine yapılan araştırmaların tüketici davranışları, tercihleri ve satın alma davranışını etkileyen faktörlere odaklandığını söylemek mümkündür (Arslan, 2003; Biş̧kin, 2004; Güngör ve İşler, 2005; Ersoy ve Firat, 2006). Araştırmacılar, tüketicilerin satın alma davranış biçimlerini ve markalara yönelik tutum ve davranışlarını anlayabilmek amaciyla gelişen bir sektör olan otomotiv sektörünün incelenmesine sıkça başvurmaktadırlar (Arıtan ve Akyüz, 2015: 214). Ancak otomotiv sektöründe marka bağlılığına dair araştırmacının ulaşabildiği literatürde sınırlı sayıda çalışma olduğu görülmüsşür.

Arıtan ve Akyüz (2015) tüketicilerin marka sadakatlerinin tespit edilmesine ve tüketicilerin ileriki dönemlerdeki marka tercihlerinin öngörülmesine yönelik çalışmalarında katılımcıların en yüksek marka sadakatini Audi markasına gösterdikleri bunun yanı sıra Mercedes, Opel markalarının da yüksek marka sadakati gösterilen markalar arasında başta geldiklerini ve genel olarak alman markalarının marka sadakatinde başı çektiğini belirtmiştir. Arıtan ve Akyüz (2015: 217) ayrıca, yazında sektörle ilgili tüketici davranışlarında büyük bir boşluk olduğu ve henüz yeterli çalışmanın yapılmadığını, gelecekte yapılacak çalışmalarla yazının desteklenmesi gerektiğini aktarmışlardır.

Yabancı literatürde ise otomotiv sektöründe marka bağlılı̆̆ına ilişkin yapılan çalışmaların kalite, memnuniyet, müşteri hizmetleri gibi bazı boyutları ön plana çıkardığı ve sınırlı sayıda olduğu görülmektedir. Vigripat ve Chan'ın (2007) otomotiv sektöründe yaptıkları araştırmada, kalitenin marka bağlılığına olumlu etkisi olduğu saptanmıştır. Bloemer ve Lemmink (1992) ise otomotiv sektöründe, yetkili satıcı ve servis hizmetlerinden kaynaklı memnuniyetin marka bağlılı̆̆ üzerine olumlu etkisi olduğunu tespit etmiştir. Ancak memnuniyetin marka 
bağl1lığı üzerindeki rolü literatürde tartışmalı bir konu olarak görülmektedir. Nitekim Dowling ve Uncles (1997) otomotiv sanayisinde, \%85 ve \%95 arasında bir oranda müşteri memnun olduğunu ifade ederken bunların \%60 veya \%70'inin farklı bir markaya geçtiğini ifade etmiştir. Benzer şekilde otomobil markaları üzerine yaptığ 1 araştırma sonucunda, memnuniyetin marka bağlılığı üzerindeki etkisinin yaş, eğitim seviyesi, medeni durum gibi demografik değişkenlere bağlı olarak farklılaşabileceğini tespit eden Mittal ve Kamakura (2001: 136), memnuniyetin marka bağlılığı üzerindeki etkisinin değişkenliğini ortaya koymuştur.

\section{YÖNTEM}

Araştırmada netnografi yöntemi kullanılmıştır. Netnografi, teknoloji aracılı çağdaş sosyal dünyanın karmaşıklığına uyarlanmış etnografi, başka bir ifadeyle internet veya teknolojik ağ etnografisidir (Kozinets, 26 Haziran 2019). Netnografi 5 aşamalı bir araştırma yöntemidir (Varnal1, 2013: 31-35). İlk aşama giriş ve araştırmanın planlanması aşamasıdır. Bu bağlamda ilk etapta araştırma soruları belirlenmiştir.

Araştırma otomotiv sektöründe marka bağlılığı nasıl oluşmaktadır sorusundan hareketle tasarlanmış, nitel araştırma ve netnografi yönteminin doğası sonucunda araştırma sürecinde otomotiv sektöründe marka bağlılığ marka bağ lılığının oluşumunda davranışsal marka bağlılığının ve tutumsal marka bağlılığının rolü nedir sorularından hareket edilmiştir. Bu bağlamda "Türkiye'de otomotiv sektöründe marka bağlılığı nasıl oluşmaktadır" sorusu araştırmanın, araştırmacı tarafından tanımlanan temel sorusudur. Araştırma sürecinde beliren alt araştırma soruları ise:

- Türkiye'de otomotiv sektöründe marka bağl1lı̆̆ oluşturabilecek etmenler nelerdir?

- Türkiye'de otomotiv sektöründeki markalara karşı marka bağlılığı oluşumunda, davranışsal marka bağlılığı ve tutumsal marka bağl1lı̆̆ kavramları ne şekilde rol almaktadir?

Uygun çevrimiçi toplulukların tespit edilmesinde kullanılacak olan anahtar kelimeler, araştırmada bilgi yüklü durumları, stratejik ve amaçlı olarak seçmeye olanak sağlayan amaçlı örneklem türü (Patton, 2014: 233, 243) dâhilinde "Toyota, Hayran (Fan) sayfası, Türkiye" olarak belirlenmiştir. $\mathrm{Bu}$ anahtar kelimeler vasıtasıyla güçlü bir ortak paydaya sahip, yüksek miktarda paylaşım yapan, çok sayıda üyeye ve yüksek paylaşım trafiğine sahip olan (Varnalı, 2013: 31) Toyota Türkiye hayran topluluğunun çevrimiçi sayfası "www.toyotaclubtr.com" araştırmada incelenmek üzere seçilmiştir.

Netnografi gibi çevrimiçi etkileşimleri derinlemesine insan anlayışı kazandırabilecek kültürel yansımalar olarak gören ve bu kültürel yansımaları analiz etmeye yarayan bir yöntemin (Kozinets, 26 Haziran 2019) kullanıldığı araştırmada, araştırmacının hali hazırda 10 yıllık bir Toyota markası kullanıcısı olması, Toyota markası kültürüne aşinalığının bulunması ve Toyota markası ile ilgili belli bir bilgi birikimine sahip olmasının araştırmaya katkı sağlayacağı düşünüldüğünden, araştırmada incelenmek üzere Toyota markası tercih edilmiştir. Ayrıca Toyota markasının dünya pazarında söz sahibi olması ve sadık bir kullanıcı kitlesi olduğunun bilinmesi de Toyota markasını öne çıkarmıştır (Statista, 26 Haziran 2019).

Netnografi yönteminin ikinci aşaması veri toplama aşamasıdır. Bu aşamada veriler araştırmanın evrenini oluşturan Toyota markasının Türkiye hayran sayfası "www.toyotaclubtr.com" üzerinde çevrimiçi olarak yapılan yorumlar arasından toplanmıştır. Evrenin büyüklüğü 14 Mart 2019 tarihindeki toplam yorum sayısı olan 1.027.397'dir. Bu yorumlar arasından marka bağ l1lığına dair içgörüler sağlayabileceği düşünülen 5 kategori altında yaklaşık 3000 tanesi, araştırmanın örneklemi olarak seçilmiştir. Bu yorumlar yine marka 
bağlılı̆̆ bağlamında değerlendirilerek, detaylı bir eleme sonucunda aralarından seçilen hayran yorumlarına bulgular bölümünde yer verilmiştir.

Netnografik araştırmanın verisini mercek altına alınan çevrimiçi toplulukların internet ortamında yarattıkları tüm metin, ses ve video tabanlı içeriğin toplanması ile oluşturulan veri havuzu, araştırmacının kendi deneyim ve gözlemlerini içeren notlar ve çevrimiçi görüşmelerin transkriptleri oluşturur (Varnalı, 2013: 32).

$\mathrm{Bu}$ araştırmada, araştırmacı yaklaşık olarak 1 ay boyunca incelenmek üzere seçilen topluluğu dışarıdan gözlemlemiştir. Daha sonra topluluk yöneticileri ile iletişime geçilmiş ve topluluğa üye olunarak, yaklaşık olarak 12 aylık bir süreyle toplulukta zaman geçirilmiştir. Araştırmada, yukarıdaki veri çeşitlerine paralel olarak 3 tip veri toplanmıştır. Bunlar; "www.toyotaclubtr.com" sayfasındaki tüm içeriklerin oluşturduğu veri havuzu içerisinden, araştırmacının katılımı olmadan alınan veriler, araştırmacının da katılımıyla, sayfa yöneticileriyle yapılan e-posta görüşmelerinin oluşturduğu veriler ve araştırmacının toplulukla ilgili gözlemlerini yazarak oluşturduğu verilerdir.

Netnografi yönteminin üçüncü aşamasını verilerin analizi oluşturur. $\mathrm{Bu}$ aşama, nitel verilerin tekrarlamalı bir yorum sürecinden geçerek analiz edilmesinden ibarettir. Bilgiler kodlanır, karşılaştırılır, sınıflandırılır ve anlamlandırılır. Yeni bir bilgi elde edildiğinde, gerek duyulduğu takdirde, o zamana kadar oluşturulan anlamlar yeniden değerlendirilir ve sinıflandırmalar yeniden yapılır. Bu süreç araştırmada elde edilecek son bilgiye kadar sürmektedir (Varnal1, 2013: 32-33).

Araştırmada izlenen detaylı nitel analiz ve yorumlama süreci şu şekildedir (Berg ve Lune, 2015: 383, 405; Creswell, 2016: 198; Tesch, 1990):

- Araştırma sorusunun belirlenmesi ve araştırma sorularına cevap verebileceği düşünülen nitel verinin toplanarak düzenli bir metin haline getirilmesi

- Nitel ham verinin okunması, bilgilerin altındaki anlamların aranması ve çözümlemeli bir şekilde kodlar geliştirilerek, kodların tümevarımsal şekilde veride tanımlanması

- Elde edilen kodlar ile kategorilerin belirlenmesi

- Kategoriler oluşturulduktan sonra kodların tekrar kontrol edilmesi, uyumsuzlukların tasnif edilmesi ve benzer ifadeler veya yakın anlamlar için kapsamlı betimsel kelimeler bulunarak kategorilerin azaltılması

- Tasnif edilen materyallerin anlamlı şablonlar ve süreçleri ayırmak amacıyla incelenmesi

- Karar verilen kategorilerle tema ve örüntülerin oluşturulması

- Bu tema ve örüntülerin, bulguların analizi ile ortaya konması, diğer araştırmalardaki teorilerle ilişki ve bağlantılarının gösterilmesi ve mevcut literatür ile ilişkilendirilmesi

- Analiz, bulgu, sonuç ve önerilerin geçerlilik ve güvenilirlik kapsamında değerlendirilmesi.

Araştırma etiğinin sağlanması netnografinin dördündü aşamasını oluşturmaktadır (Varnalı, 2013: 33-34). Bu araştırmada, araştırmaya başlamadan söz konusu çevrimiçi topluluk "www.toyotaclubtr.com" yöneticileri ile iletişime geçilerek araştırma hakkında kapsamlı bilgi verilmiştir. Araştırmanın yalnızca akademik kalacağının güvencesi verilmiş ve topluluk yöneticisinden araştırma için onay alınmıştır. Ayrıca veriler arasından araştırmaya dahil edilenleri oluşturan kişilerin kimliklerinin gizli tutulması amacıyla bu kişilere kod adlar verilmiş, bulgular bölümüne bu kod adlar yansıtılmıştır.

Netnografinin son aşaması üye kontrolleridir. Araştırmanın genel çıkarımlarının kontrol edilebilmesi açısından danışılabilecek en doğal ve yetkin bilirkişiler yine incelenen topluluğun üyeleri olacaktır (Varnalı, 2013: 34). Üye kontrolleri, nitel bir araştırmanında inanılırlı̆̆ın 
sağlanması açısından, Guba (1985) tarafından en kritik teknik olarak vurgulanmaktadır. Bu teknikte araştırmanın sonuçları katılımcılara gönderilerek, ortaya konan açıklamaların inandırıcılığı ve doğruluğu hakkında katılımcıların görüşleri alınır ve değerlendirilir (Creswell, 2016: 252). Bu bağlamda araştırmanın sonuçları, derinlemesine bir fikir alışverişi yapılması amacıyla bazı araştırma katılımcılarına ulaştırılarak üye kontrolleri sağlanmıştır. Ayrıca araştırma sonuçları, topluluk yöneticileriyle de paylaşılarak, topluluğun kültürüne en çok aşina olan yöneticilerin de fikirleri değerlendirilmiştir.

Nitel araştırma sürecinde geçerlik ve güvenilirliğin sağlanması amacıyla Creswell'in (2016) geçerlilik stratejileri arasından; alanda uzun süreli zaman geçirilmesi, akran incelemesi, üye kontrolleri ve dış denetimler stratejileri uygulanmıştır. Ayrıca Lincoln ve Guba'nın (1994) geçerlilik ve güvenilirliği karşılayan güvenduyulabilirlik kavramından yararlanılmıştır. Bu kapsamda inandırıcılık (credibility), aktarılabilirlik (transferability), güvenilebilirlik (dependability) ve onaylanabilirlik (confirmability) ölçütleri sağlanmıştır. Bunlara ek olarak netnografi yöntemi açısından güvenilirlik kavramının sağlanması için Varnalı'nın (2013) önerileri dikkate alınmıştır.

\section{BULGULAR}

Toyota markasının Türkiye hayran topluluğunun çevrimiçi sayfası "www.toyotaclubtr.com" topluluk bilinci, ahlaki sorumluluk ve paylaşlan ritüellerin (Muniz ve O’Guinn, 2001) varlığıyla marka topluluğu özelliği göstermekte ve sanal bir marka topluluğu olarak faaliyet göstermektedir.

Hayran sayfasının incelenmesi sonucunda "Marka bağlilığı oluşturabilecek etmenler" ortak örüntüsü altında 6 ana örüntüye ulaşılmıştır. Oluşan örüntüler ve alt boyutları davranışsal marka bağl1lığ 1 ve tutumsal marka bağl1lığ1 açısından değerlendirilmiştir. Her bir örüntü ve alt boyutun altında ilgili kullanıcı yorumları verilmiştir.

\section{1. Marka Bağlılığı Oluşturabilecek Etmenler}

\subsubsection{Menşe Ülke Etkisi}

Menşe ülke imajı Nagashima'ya (1970) göre tüketicilerin söz konusu ülkenin ürünlerine yüklediği anlam, itibar, tanımlama, tasvir ve tutum kalıplarını ifade etmektedir. Parameswaran ve Yaprak (1987) ise belirli bir ülkede üretilen ürünler hakkındaki tüketicilerin genel anlayışlarının menşe ülke imajını yansıttığı belirtmiştir. Menşe ülke imajlarının ve menşe ülke bilgisinin ürün tercihinde ve karar verme sürecinde, özellikle günümüzde giderek bilinçlenen tüketiciler üzerinde önemli etkisi vardır (Cengiz, 2009; Verlegh ve Steenkamp, 1999). Hayran sayfasına bakıldığında otomotiv sektöründe de menşe imajının rolü olduğu ve hem olumlu tutumlar hem de tekrar satın alma noktasında marka bağlılığı yaratmada rol oynadığı görülmüştür.

Kullanıc1-16 (2005): Ben babadan Toyota'cıyım. Babam beş sıfır araba aldı bunları dört tanesi Japon malıydı (o bir tane de tofaş) Isuzu, Mazda, Toyota yani benim çocukluğum Japonların arasında geçti. Babam her zaman Japon araçların sorunsuz, kaliteli, yaklt tüketimin daha az olduğunu söyler. Neden toyota? Babam elektronikle uğraşlyor. Bildiğimiz gibi Japonlar elektronikte zirvedeler. Elektronikteki bu gelişmişlik arabalara yansiyor haliyle. Onun için Toyota'clyzz.

Roth ve Romeo (1992), Verlegh ve Steenkamp (1999) gibi birçok araştırmacı araştırmalarında Japon elektronik ürünlerinin yüksek kaliteli olarak algılandığını ortaya koymuştur. Benzer şekilde Kullanıcı-16, menşe ülke etkisi sonucu kendisinde oluşan algının 
Japonların teknoloji konusundaki yetkinlikleri olduğunu göstermektedir. Ayrıca deneyimleri sonucu Japon otomobillerini sorunsuzluk, kalite ve düşük yakıt tüketimi ile ilişkilendiren kullanıcı, bu sebeplerle "Toyotacı" olduklarını belirtmiştir. Japon markalarının teknoloji konusundaki gelişmişlikleri göz önünde bulundurulduğunda ve tüketiciler tarafindan yüksek kaliteli algılandığ 1 (Roth ve Romeo, 1992) düşünüldüğünde kullanıcının ortaya koyduğu genel anlayışının menşe etkisinden kaynaklandığını söylemek mümkündür. "Toyotacıyız" ifadesini kullanan Kullanıc1-16'nın markaya karşı olumlu bir tutum oluşturduğu ve bu tutum sonucunda markayı tekrar tercih etme ihtimalinden bahsettiği görülmektedir.

Otomotiv sektöründe menşe ülke etkisinin marka bağl1lı̆̆ üzerindeki rolüne dair Toyota markası dışındaki markalarla ilgili bir genelleme yapılamamakla birlikte hayran sayfasında Japon markalarının yanı sıra Alman markalarına karşı da menşe ülke etkisinin marka bağlılı̆̆ üzerindeki rolünü gösteren yorumlara rastlanmış ancak araştırmada Toyota markası incelendiğinden bulgularda bu yorumlara yer verilmemiștir. Hali hazırda sektördeki en büyük pazar paylarını paylaşan (Statista, 26 Haziran 2019) Alman ve Japon menşeli markaların otomotiv sektöründe yarattıkları menşe ülke imajına dayanarak (Brodowsky, 2004; Verlegh ve Steenkamp, 1999) bu durumun Alman markaları için de geçerli olduğunun söylenebileceği ancak farklı ülkelerin menşe etkilerinin ayrı bir araştırma konusu olarak ele alınması gerektiği belirtilebilir.

\subsubsection{Markaya Özgü Nitelikler}

Otomotiv sektöründe bir markanın tekrar tercih edilmesi veya markaya karşı olumlu tutumlar oluşturulmasında, tüketicilerin aradığı niteliklerin markalarda olmasının önemli olduğu araştırma bulgularında görülmektedir. Bu noktada markaların tekrar tercih edilmesine veya markaya karşı olumlu tutumlar oluşturulmasına neden olan niteliksel özelliklerin tespit edilmesi gerekmektedir.

Toyota hayran topluluğuna bakıldığında, Toyota markasının tercih edilmesinde rol oynayan en önemli niteliklerin; sorunsuzluk, sağlamlık ve dayanıklılık, güvenlik, güven ve kalite olduğu görülmüştür. Birbirleriyle bağlantılı bu boyutların birçoğu kullanıcılar tarafından birlikte vurgulanmaktadir.

\subsubsection{Sorunsuzluk}

Sorunsuzluk hayran sayfasındaki kullanıcılar için problemsiz olma, problem çıkarmama, arıza yapmama gibi benzer durumları temsil etmektedir. Toyota markasının kullanıcısı olsun veya olmasın, Toyota markasının sorunsuzluğu geniş kesimlerce bilinmekte ve vurgulanmaktadır. Nitekim J.D. Power kuruluşunun (2017) yaptığı, en sorunsuz ve en az arıza yapan otomobil markalarını açıkladığı araştırmada Toyota markasının üst sıralarda yer alması (J.D. Power, 20 Mayis 2019) ve Consumer Reports'un (2018) en sorunsuz 20 otomobil markasının modellerini sıraladığı araştırmada Toyota markasının birçok modelinin bulunması (otopark.com, 18 Mayıs 2019) bu durumu doğrular niteliktedir. Markayı sorunsuz olduğu için tercih ettiğini ve tekrar tercih edeceğini söyleyen kullanıcılar üzerinde sorunsuzluk boyutunun uzun vadeli ilişkiler yaratmada rolü olabileceği görülmüştür. Kullanıcı-9 "Neden Toyota" konu başlığı altındaki cevabıyla bu durumu ortaya koymuştur:

Kullanıc1-9 (2018): Toyota marka olarak sorunsuzluğa ve müşteri hizmetlerine önem verdiği için Toyota geçmişimiz vardl, sorunsuzluğunu biliyordum. Toyota'yı sorunsuzluğundan ve müsteri memnuniyetine önem verdiğinden dolayı tekrar tercih edebilirim. 
Kullanıc1-9 sorunsuzluk boyutunun kendisinde bıraktığı izlenimler sonucunda markayı tekrar tercih edebileceğini ifade etmiştir. Tüketicinin markaya karşı bağlanmasında sorunsuzluk boyutunun rolü olduğu görülmektedir. Kullanıc1-9'un yorumuna bakılarak daha çok davranışsal bir marka bağl1lı̆̆ yaratma noktasında rol aldığ düşünülebilecek sorunsuzluk boyutunun, olumlu tutumlar yaratma konusunda da rol alabildiği görülmüsstür. Örneğin Kullanıc1-26:

Kullanıc1-26 (2012): Kendimden bir parça, sorunsuz, sorunları olduğunda hıla çözüme kavuşturulan, düşünmeden yola çıkabileceğim evimin sokaktaki konforlu tarafi.

Kullanıc1-26 otomobiliyle ilgili bir olumsuz durum yaşamadığını ifade ederek sorunsuz olduğunu belirtmekte ve marka hakkında açılan başlıkta "kendimden bir parça" ifadelerini kullanarak sorunsuzluğun olumlu tutumlar yaratma noktasında rolü olduğunu göstermektedir. Kullanıcının otomobilinin sorunsuzluğu vasitasıyla oluşturduğu olumlu tutumların gelecekte markayı tekrar tercih etme noktasında önemli rolü olacağı söylenebilir.

Sorunsuzluk boyutunun, sorun çıkarmayan bir otomobilin uzun süreler kullanılabileceği düşünüldüğünde, aynı zamanda uzun süreli kullanım noktasında da rolü olduğu görülmüsstür. Dolayısıyla sorunsuzluk boyutunun, marka bağlılığ yaratmada hem doğrudan hem de yol açtığı memnuniyet, güven, uzun süreli kullanım gibi boyutlarla dolaylı olarak rol alabildiği söylenebilir.

\subsubsection{Sağlamlık ve Dayanıklılık}

Birbirine çok yakın kavramlar olan ve birbirini kapsayan sağlamlık ve dayanıklılık temel olarak sağlam olma, dışarıdan gelecek etkilere dayanıklı olma anlamında kullanılırken (TDK, 10 Mart 2019), hayran sayfasında bu anlamların yanı sıra, markanın sorunsuzluğu, uzun süreler kullanılabilmesi, geç yıpranması, nadiren arıza yapması gibi anlamları içerecek şekilde kullanıldığ1 görülmüştür. "Neden Toyota" konu başlığı altında sağlamlığa vurgu yapan ve otomobili ile arasında bir bağ bulunduğunu belirten Kullanıc1-1 ve Kullanıc1-10, sağlamlık ve dayanıklılığın kendileri için neyi ifade ettiğini aktarırken aynı zamanda markayı tekrar tercih etme eğilimde olduklarını ve olumlu tutumlarını da ortaya koymuştur.

Kullanıc1-1 (2018): Bir kere sağlam araba. Yıllara meydan okuyor. Kullanım hissi yumuşak. 10 yıldır kullandığım Corolla için bunları söylüyorum. Başka araba alacak olsam yine Toyota. Inş̧allah yine Corolla ama sifir araba fiyatlarlyla zor. Bu arada aramızda bir băg var. Toyota gerektiği kadar ve işlevsel bir marka. Büyük marka büyük.

Kullanıc1-10 (2018): Sinıfinın en sağlam, dayanıkl, yaklşıklı, ergonomik, sorunsuz ve konforlu araçlarından biri olması olabilir. Ayrıca iç malzeme kalitesi ve yıllara meydan okuyan iç malzemenin kolay kolay yıpranmaması.

Kullanıc1-1 başta sağlamlık olmak üzere kendisi için önemli bulduğu boyutların otomobilinde bulunmasının etkisiyle, hem markayla arasında bağ oluştuğunu hem de başka bir otomobil tercihi yapması durumunda yine Toyota markasını tercih edeceğini belirtmektedir. Bu durum otomobillere özgü bazı niteliklerin hem davranışsal hem de tutumsal bir marka bağ lılığı yaratma noktasında rolü olduğunu göstermektedir. Kullanıc1-1'in markaya özgü bu nitelikler sayesinde hem davranışsal hem de tutumsal olarak markaya karşı oluşturduğu bağ, gerçek bir marka bağlılığı yaratma noktasında sağlamlık, dayanıklılık, sorunsuzluk gibi boyutların rolünü göstermektedir. Kullanıc1-10 da benzer şeklide bu boyutların markayı sevmesine neden olduğunu belirtmektedir. İki kullanıcının ortak olarak kullandığ 1 "yıllara meydan okuyor" kalıbı dikkat çekerken, bu boyutların markayı uzun süre kullanma imkânı verdiği görülmektedir.

$\mathrm{Bu}$ ve benzer yorumlara bakıldığında sorunsuzluk, sağlamlık, dayanıklılık gibi birbirinden farklı ancak yakından ilişkili olan boyutların tüketicileri etkilediği ve bu boyutların hem olumlu tutumlar bıraktığı hem de markayı tekrar tercih etme noktasında tüketicileri 
yönlendirdiği, dolayısıyla marka bağlılı̆̆ yaratılması açısından rolü olduğu görülmektedir. Sağlamlık ve dayanıklılık boyutlarının otomobilleri aynı zamanda güvenlik açısından da ön plana çıkardığ 1 ve markaya karşı güven duygusu oluşturmada rolü olduğu görülmüştür. Yine sağlamlık ve dayanıklılık boyutlarının uzun süreli bir kullanıma yol açacağı, bu açıdan uzun süreli kullanım üzerinde rolü olduğu görülmüştür.

\subsubsection{Güvenlik}

Ersoy ve Frrat'in (2006) Türkiye'de otomotiv sektöründe tüketici tercihlerine üzerine yaptığı araştırmada, tüketicilerin en çok önem verdiği boyutlardan olan güvenlik, otomobil sektörünün geleceği açısından da önemli bir boyuttur. Güvenlik boyutunun hayran sayfasında da aynı önemi gördüğü söylenebilir. Güvenlik açısından tüketicilere göre yetersiz bir markanın, tekrar tercih edilme ihtimalinin düşebileceği ve bu durumun marka bağl1lığ ön plana çıkardığını söylemek mümkündür. Hayran sayfasında güvenlik boyutu kaza ve kaza durumlarındaki sağlamlık ve dayanıklılık ile ilişkilendirilerek kullanılmaktadır. Hayran sayfasında güvenliğin önemini ve kendisi için ne ifade ettiğini K36 şu şekilde belirtmektedir:

Kullanıc1-36 (2009): 1-Güvenlik: Bu olmadan Allah korusun diğerlerinin hepsi bir kaza esnasinda hava civadir...

Kullanıcı-36 güvenlik olmadan diğer boyutların önemsiz olacağını vurgulamaktadır. Kullanıcıların otomobil satın alma kriterlerinde ön sıralara koyduğu güvenlik boyutu bu açıdan sadece Toyota markası için değil otomotiv sektörü için uzun vadeli ilişkiler ve marka bağlılığı yaratmak açısından önemli bir boyut olarak ön plana çıkmaktadır.

\subsubsection{Kalite}

Kalite temel olarak nitelik anlamına gelen (TDK, 12 Mart 2019) son derece kapsamlı bir terimdir. Literatürdeki algılanan kalite kavramı baz alındığında ise tüketicilerin bir ürüne karşı öznel yargıları olarak tanımlanabilir (Zeithaml, 1988). Aaker (1999) kaliteyi hayran sayfasındaki durumla benzer bir şekilde tüketicilerin algısı olarak göstermektedir. Bu doğrultuda topluluktaki üyeler tarafindan kullanılan kalite kavramının taşıdığı farklı anlamlara rağmen ortak bir algıyı temsil ettiği düşünüldügünden, marka bağlılığı yaratabilecek niteliksel özellikler altında verilmesi uygun görülmüştür. Hayran sayfasının kültürü içerisinde kalite kavramının kapsamlı bir algıyı yansıttığı ve otomobillere dair olumlu özelliklerin birçoğunu bir arada toplayan bir kavram olarak ifade edildiği görülmüştür. Hayran sayfası bağlamında Toyota markası, bir otomobile özgü özelliklerin birçoğunda, belli bir seviyenin üstünde bir marka olarak değerlendirilmektedir. Konuyla ilgili bazı yorumlar aşağıdaki gibidir:

Kullanıc1-28 (2012): Kalite, unutulan sanayi yolu, pazara düşmeden elden ele gezen arabalar.

Kullanıc1-28 "Toyota denince aklınıza gelen ilk şey” konu başlığı altında ilgili yorumu yapmıştır. Kullanıcı, markanın kalitesine, sorunsuzluğuna ve ikinci el performansı boyutlarına birlikte değinmiştir. Bu gibi boyutların önceki yorumlarda hem davranışsal hem de tutumsal marka bağl1lığı yaratmada rolü olabildiği görülmüştür. Kullanıcı-28 "unutulan sanayi yolu" ve "pazara düşmeden elden ele gezen arabalar" gibi ifadelerle markanın kalitesini kendi zihninde nasıl konumlandırdığını ve markanın kendisine göre bu konumlandırma sonucu seçkin bir marka haline geldiğini "kalite" kavramı ile ifade etmektedir. Kalite konusunda bu gibi markayı belirgin bir şekilde ötekilerden ayıracak öznel yargıların marka bağlılı̆g 1 yaratma noktasında rolü olduğu görülmüştür. Bu açıdan kalite algıları yaratmak son derece önemlidir (Aaker, 1991). 
Toyota markasının kalitesine "seneler yıpratamıyor ki biz yıpratalım" ifadesiyle vurgu yapan Kullanıcı-50, sağlamlık ve dayanıklılık, sorunsuzluk boyutlarının sonucu oluşan kalite algısını "Toyota kalitesi tartışılmaz" ifadesiyle "Kullandığınız arabanın yaşı nedir?” konu başlığı altında ortaya koymuştur:

Kullanıc1-50 (2007): 6,5 senelik benim aracımda ama hala yeni nesil birçok araca taş çıkartır kalitede olduğu kanaatindeyim. Zaten Toyota kalitesi tartışılmaz. Seneler Toyota'yı yıpratamiyor ki biz yıpratalım.

Aaker'e (1999: 107) göre algılanan kalite bir marka hakkında genel ve soyut ifadeleri içerse bile markanın ürünlerinin gerçek özelliklerine dayanmaktadır. Bu bağlamda hayran sayfasındaki yorumlarda kalite algısının, sorunsuzluk, sağlamlık ve dayanıklılık ve güvenlik boyutlarına, bir başka deyişle Toyota markasının marka bağlılığı yaratılması noktasında ön plana çıkan niteliksel özelliklerine ve menşe ülke imajının yarattığı algıya dayanarak oluşabileceği de söylenebilir. Bu noktada menşe ülke etkisi bu boyutları genel bir anlayış olarak tüketicilerde oluştururken, tüketiciler gerçek deneyimleri sonucu bu boyutlardan memnun kalmakta ve markayı tekrar tercih edeceklerini veya olumlu tutumlarını hayran sayfasina yorum olarak taşımaktadır. Bu açıdan sorunsuzluk, sağlamlık ve dayanıklılık, menşe ülke imajı boyutlarının, kalite boyutunun oluşumunda rol oynadıkları da görülmektedir.

\subsubsection{Güven}

Morgan ve Hunt'a (1994) göre güven marka bağlılı̆̆ının belirleyicilerinden biridir. Cunningham'ın (1999) tüm istikrarlı ilişkilerin temeli olarak gördüğü güven boyutu diğer boyutlarla ilişkili ve iç içe geçmiş bir boyuttur. Hayran sayfasında güven boyutu farklı durumları ifade edebilmekle birlikte genel olarak markanın veya otomobilin tüketicilere verdiği güven duygusu olarak ifade edilmektedir. Bu açıdan literatürdeki marka güveni kavramı ile benzerlik göstermektedir. Ancak belli noktalarda markaya duyulan güvenden ziyade, kullanıcıların marka ile ilgili bir boyut sonucu geliştirdikleri güvenin marka güvenine dönüşmesi şeklinde gelişmektedir. Ayrıca güven boyutu bu araştırmada Toyota markası ve otomobilleri bağlamında markaya özgü bir nitelik olarak ortaya çıkmaktadır. Bu açıdan güven boyutu, marka güveni yerine markanın taşıdı̆̆ 1 bir nitelik olarak markaya özgü nitelikler örüntüsü altında güven verme, markanın sağladığı güven anlamına gelecek şekilde ele alınmıştır.

Marka bağlılı̆ı yaratma noktasında markaya ve otomobiline güven duyulması otomotiv sektörü açısından önemlidir. Bişkin (2004) otomotiv sektöründe genel olarak markaya duyulan güvenin bir başka deyişle markanın güvenilirliğinin, kesin satın alma kararına etki ettiğini belirtmektedir. Bu bağlamda güven boyutunun tekrar satın alma davranışında ve marka bağlılığı yaratma noktasında rolü olduğu hayran sayfasındaki yorumlarla birlikte görülmektedir.

Kullanıc1-27 (2012): Toyota=güven ve kalite...

Ar'a (2007: 85-86) göre yüksek kalite ve uzun garanti süreleri gibi unsurlar müşteriye güven sağlar ve bunlar her markanın uygulaması gereken unsurlardır. Kullanıc1-27 markanın kendisinde ilk olarak güven ve kalite boyutlarını çağrıştırdığ görüşüyle örtüşecek şekilde, Kullanıcı-27 adlı kullanıcı açısından, markanın kendisinde önce gerçek deneyime veya menşe ülke etkisine bağlı olabilecek şekilde kalite algısını oluşturduğu, sonra ise markanın kalitesinin kendisinde markaya karşı güven oluşturduğu söylenebilir. $\mathrm{Bu}$ açıdan kalitenin güvenle ilişkili bir boyut olduğu ve her iki boyutunda marka bağlılığı oluşumunda rolü olduğu söylenebilir. Nitekim Vigripat ve Chan (2007) otomotiv sektöründe yaptıkları araştırmada hizmet kalitesi ve marka güveninin marka bağlılığı üzerine olumlu etkilerini ortaya koymuştur.

$$
\text { Kullanıc1-32 (2012): Toyota (o varsa sorun yok). }
$$


Kullanıcı-32 de benzer bir şekilde markaya olan güvenini "o varsa sorun yok" şeklinde ifade etmiş ve bir anlamda markanın sorunsuzluğunun da kendisinde bir güven yarattığını vurgulamıştır. Burada kullanıcının marka güveninin yanı sıra marka vasıtasıyla kendini de güvende hissettiği ve "toyota varsa sorun yok" mesajını vererek marka veya otomobiliyle ilgili bir olumsuzluk yaşamayı beklemediği görülmektedir. "O varsa sorun yok", "Çıkarım senle her yola", "Yarı yolda bırakmaz Toyota" gibi ifadelerin hayran sayfası kültüründe markaya ve markanın otomobillerine karşı bir güven ifadesi olarak kullanıldığ görülmektedir.

\subsection{Uzun Süreli Kullanım}

Aaker (2009: 60) uzun vadeli bir ilişki söz konusu olduğunda insanların bir șeyi neden sevdiklerini, beğendiklerini saptamanın zor olduğunu, bazen yalnızca uzun süreli bir ilișkinin, saptanabilir boyutlar olmaksızın güçlü bir etki yarattığını ve duygusal bağlara neden olduğunu belirtmiştir. Hayran sayfasında da benzer bir şekilde uzun süreli kullanımın markaya karşı alışkanlık oluşturabilmesinin yanı sıra olumlu tutumlar yaratmada ve duygusal boyutları tetiklemedeki rolü görülmektedir. Kullanıc1-6 "Neden Toyota" konu başlığı altında:

Kullanıc1-6 (2018): 1986'dan beri hep birçok farklı modelde toyota ee alışınca birakamiyor insan.

Kullanıcının 1986 yılından beri farklı modellerde Toyota markasını kullandığ 1 ve bu uzun sürecin kendisinde alışkanlık yarattığı görülmektedir. Uzun süre aynı otomobil kullanılmasının otomobile ve markasına karşı alışkanlığa ve bağlılığa yol açacağ 1 ve tekrar aynı markanın tercih edilmesine neden olabileceği kullanıcının yorumundan anlaşılmaktadır.

Uzun süre kullandıkları araçlarına karşı bağ oluşturduğunu ve artık aileden biri gibi gördüğünü ifade eden bir diğer kullanıcı:

Kullanıc1-137 (2012): Babam arabasız duramaz imkânı olsa tuvalete arabayla gider derler ya tam o kafadandir, bekleyemedi ve 97 model metalik grilyeşil bir Corolla'mız oldu. 2009 yılında pert olana kadar bizdeydi ve artık araç aileden gibiydi, yahu bir ruhu vardı sanki.

Kullanıcı-137 uzun bir süre kullandıkları araçlarının artık aileden biri gibi olduğunu ve ruhu olduğunu belirtmiştir. Duygusal olarak otomobile bağlandığını görülen kullanıcının otomobiline karşı oluşturduğu bu olumlu tutumların uzun süreli kullanım etkisiyle oluştuğu ve uzun süreli kullanımın marka bağlılığı noktasındaki rolü görülmektedir.

Markaya bağl11ık oluşturabilecek olan sorunsuzluk, sağlamlık ve dayanıklılık, güvenlik, kalite ve güven boyutlarının her birinin markanın uzun süre kullanılabilmesinde rolü olduğu görülmüştür. Bu doğrultuda otomobillerinde bu nitelikler mevcut olan kullanıcıların, uzun vadeli bir kullanım sonucu duygusal bağll1ıklar geliştirdikleri görülmektedir. Otomobillerine duygusal açıdan bağlılık gösteren kullanıcıların birçoğunun uzun süre aynı otomobili kullandıkları dolayısıyla uzun süreli kullanım ve duygusal bağlılık arasında bir ilişki olduğu ve bu ilişkinin de marka bağlılığ boyutunun otomotiv sektöründe marka bağ lılığ yaratılması açısından doğrudan ve dolaylı rolü olduğu görülmüştür.

\subsection{Duygusal Bağlılık}

Güneş (2012) Türk toplumunda otomobilin bir fetiş nesne olarak toplumu kendine bağladığını, kendini dışa vurma ihtiyacını gidermeye yaradığını ve kimi zamanlarda sevgili, arkadaş gibi mertebelere ulaştığını ifade etmiştir. Otomobilin işlevinin çok ötesine geçerek psikolojik ve duygusal etkilerinin olduğunu ve Türk toplumunun bunlardan etkilendiğini söylemek mümkündür. Özellikle Türk toplumunda, otomobillere karşı duygusal açıdan bir 
bağl1lığın rahatlıkla oluşabildiği ve bu durumun marka bağlılığı yaratma noktasında rol alabildiği söylenebilir. Literatürde marka duygusu olarak; tüketicinin markayla ilgili tüm duygusal değerlendirmeleri (Matzler vd. , 2008) şeklinde tanımlanan kavramın, gerçek marka bağl1lığının belirleyicilerinden biri olduğu belirtilmektedir. Özellikle tüketicilerin mutlu olmasını sağlayan veya kullanımı haz veren markalar, tüketicinin markaya olan tutumsal bağlılığını güçlendirmekte ve tekrar eden satın alma davranışlarına yol açmaktadır (Chaudhuri ve Holbrook, 2001). Hayran sayfasındaki yorumlar üzerinden kullanıcıların farklı şekillerde otomobillere veya markalarına karşı duygusal bağl1lık geliştirilebildiği görülmüştür.

\subsection{1. İlklere Duyulan Bağ}

Sosyal hayatta sıkça kullanılan "ilkler unutulmaz, ilklerin yeri ayrıdır" gibi kalıplar hayran sayfasında, kullanıcıların otomobil hikâyelerinde geçmektedir. Her insan için ilklerin duygusal bir bağ yaratabileceği söylenebilir. Goethe (2007) ilklerle ilgili olarak; "ilk izlenimler insanların zihnine yapışıp kalırlar ve onları silmek ya da yok etmek isteyenlerin vay haline" ifadeleriyle ilk izlenimlerin unutulmaz izler bırakabildiğini vurgulamıştır.

Kullanıc1-211 (2018): Illk aracım 2008 Aralık ayında aldiğım 2001 otomatik Corolla vvt$i$ Terra idi. Bilen bilir sürüss zevki bağımlılık yapan mükemmel araçlardandır. Hatta o zaman vw bora arabası olan bir arkadaşım aracımı ilk gördüğünde burun kıvırmıştı ama arabamla bir tur attıktan sonra arabadan zor indirdim ya ben Toyota'yı böyle bilmiyordum, sürüşü çok zevkliymiş, tıpk bilgisayar oyunu gibi demişti. Ben de aman üstat dikkat et, tek canımız var diye espriyi patlatmışıtım tek canımız kaldıyı bizim kuşak atari oynayanlar iyi bilir. O aracımı satıp 2001 Civic almıştım ama Corolla'daki o sürüş zevkini ve güveni bulamamıştım.

\section{Illkler gerçekten unutulmuyormuş.}

Kullanıc1-211 "ilkler gerçekten unutulmuyormuş" ifadesiyle sattığı otomobilinin kendisi için ilk olması sebebiyle çok farklı izler bıraktığını ve duygusal bir bağ oluşturduğunu ifade etmiştir. Kullanıcı-211 açısından davranışsal bir bağlılık yaratmasa dahi tutumsal açıdan kullanıcı da bıraktığı olumlu tutumların ileride tekrar markaya dönmesine yol açabileceği düşünülmektedir. Kullanıc1-15 de bu düşünceyi destekleyecek şekilde otomobillerine karşı ailece kullandıkları ilk araç olması sebebiyle besledikleri olumlu tutumları ifade etmiştir.

Kullanıc1-15 (2015): Ailecek ilk aracımız olması sebebi ile hepimiz çok seviyoruz, eşim içinin ferah olması ve arka tarafin geniş olmasından dolayı memnun. Kızım arabanın sahibi zaten. Bazen iş vb. sebeple sabahları kullandiğımda telefon ile arayıp bana klzıyor: "Baba bir daha arabami alma" diye.

\subsubsection{Bir Kez Toyota Kullanılması}

Hayran sayfasında rastlanan bir diğer bulgu ilk kez kullanıma benzer olarak bir kez Toyota markasının kullanılması durumunda oluşacağına inanılan bağdır. Kullanıcılar Toyota ile bir kez tanıştıktan sonra kolay kolay markadan vazgeçilemeyeceğine inanmaktadır. Bu durumun farklı markalar için de geçerli olabileceği yorumlardan görülmektedir. Dolayısıyla markaya karşı bağlılık oluşturma noktasında bir kez Toyota kullanılması veya bir markanın bir kez tercih edilmesi olarak etkili olabilecek bir boyut görülmüştür. Kullanıc1-37 (2018) bu görüşe paralel olarak başka bir kullanıcıya hitaben kullandığı:

"Esat Bey Toyota ve Mercedes bir bağımlılıktır bir sefer bindiğiniz zaman tekrar döner, dolaşır bir Toyota modeli alırsiniz."

ifadeleriyle bu durumun sadece Toyota markasına has olmadığını, farklı bir markanın da bir kez kullanılması durumunda bağımlılık yaratacağına inandığını belirtmiş̧tir. Bu durum 
kişiden kişiye değişebilecek bir değerlendirme olmasıyla birlikte hayran sayfasındaki kullanımı, bir kez kullanıldığında bağımlılık yaratacak olan markaların, birçok özellik açısından belli bir seviyenin üzerinde olduğu ve tüketicilere göre diğer markalardan bir noktada belirgin bir şekilde ayrıldığı ve duygusal açıdan da bağlılık yarattığı şeklindedir. Hayran sayfası kültüründe bir kez Toyota kullanılması şeklinde kodlanan boyutun, literatürde marka bağlılığını doğrudan ve dolaylı etkilediği ortaya koyulan marka deneyimi kavramıyla da ilişkili olduğu söylenebilir (Brakus vd. , 2009).

\subsubsection{Otomobillere İnsanlara Özgü Nitelikler Yüklenmesi}

Markaların insansı özellikler kazandığını belirten Kotler vd. (2018) pazarlama uzmanlarının bu yeni gerçekliğe uyum sağlamaları gerektiği ve insan gibi davranan markalar yaratmaları gerektiğini ifade etmektedir. Bunu başaran markaların duygusal bir bă̆ yaratabileceği düşünülmektedir. Bu duruma benzer şekilde hayran sayfasında otomobillerin ve markaların insan gibi görüldügüne, insana özgü niteliklerin otomobillere ve markalarına yüklendiğine rastlanmıştır. $\mathrm{Bu}$ durum otomobil markalarına karşı olumlu bir tutum oluşturabilmektedir. Kullanıcı- 80 otomobili için kullandığ 1 "ergenliğe yeni adım atıyor daha çok genç" ifadeleriyle bu durumu göstermektedir. Kullanıcıların, otomobillerine karşı duygularını açığa çıkardıkları, sevgilerini ve bağlılıklarını gösterdiği bu gibi durumların marka bağlılığı açısından, özellikle olumlu tutumlar yaratmada rolü olacağı düşünülmektedir.

Kullanıc1-80 (2011): Ergenliğe yeni yeni adımlar atıyor, 14 yaşında çok genç daha...

Kullanıcıların otomobillerini insan gibi gördükleri ve insana özgü niteliklerle otomobillerini tasvir etmenin yanı sıra insanların birbirlerine karşı beslediği duyguları otomobillerine karşı geliştirdikleri görülmektedir. Otomobillere karşı yüklenen bu gibi duygusal özelliklerin markalarına karşı da olumlu tutumlara yol açacağı ve marka bağlılığ yaratılması noktasında rol alabileceği, tekrar satın alma noktasında da markayı öncelikli hale getireceği düşünülmektedir. Nitekim Kotler vd. (2018) bu gibi markaların müşterileriyle birer arkadaş haline gelerek onların yaşam biçimlerinin ayrılmaz bir parçası olabileceğini savunmaktadır. Ayrıca uzun süreli kullanım sonucunda da otomobillere insan özgü nitelikler yüklenmeye başladığı görülmüş dolayısıyla uzun süreli kullanımın da bu boyut üzerinde rolü olduğu saptanmıştır.

\subsubsection{Otomobillerin Bir Aile Ferdi Gibi Görülmesi}

Otomobilleri ile duygusal olarak kurdukları bağları, otomobillerini bir aile ferdi gibi nitelendirmeleri vasıtasıyla yansıtan kullanıcıların yorumlarına bakıldığında, otomobillerine karş1 olumlu tutumlarının zamanla markaya karşı bir bağlılığa yol açabileceği düşünülmektedir.

Kullanıc1-62 (2008): 2 yaşında kızım.

Kullanıcı-62 yorumuyla otomobiline olan bağını otomobilini kızı olarak gördüğünü ifade ederek, otomobilini bir aile ferdi yerine koyduğunu göstermektedir. K65 de benzer bir yorumla:

Kullanıcı-65 (2008): Tam 17 yaşında yani 1991 model, ama çoğu 2001'lere taş çıkartır benim oğlum.

Kullanıcı-65 gibi kullanıcılar görece yaşlı araçlarının yeni birçok araca taş çıkartacağını belirterek araçlarına duydukları güveni de ifade etmektedir. Özellikle uzun süreli kullanımda otomobillerin aile fertleri yerine koyulduğu görülmüștür. $\mathrm{Bu}$ açıdan uzun süreli kullanımın otomobillerin aileden biri gibi görülmesinde rol oynadığını söylemek mümkündür. Otomobile karş1 oluşan bu gibi olumlu tutumların, otomobillere insana özgü nitelikler yüklenmesi 
boyutunda olduğu gibi markaya karşı olumlu tutumlara ve dolayısıyla marka bağl1lığına yol açabilecek durumlar olduğu düşünülmektedir.

\subsubsection{Geçmiş ve Anıların Etkisi}

Literatürde nostaljik öğelerin özellikle postmodern tüketiciler üzerindeki etkilerini ele alan çalışmalar olduğu bilinmektedir. Odabaşı'ya (2004) göre postmodern bireyler geçmişle bağ kurmaktan ve onu bugüne taşımaktan büyük haz almaktadır. Zihinsel süreçlerin günümüz tüketim kültüründeki etkisi düşünüldüğünde bu durumun güçlü bir marka bağl1lığ1 oluşturabileceğini söylemek mümkündür. Hayran sayfasındaki yorumlarda geçmişten kalan izlerin gelecekteki satın alma davranışı üzerinde tutumsal açıdan rolü olduğu ve oluşturacağı duygusal bağl1l1k sonucu markayı tekrar tercih etmesine neden olabileceği görülmüştür.

Kullanıc1-135 (2012): Ben lise ylllarındeyken dedem almıştı kedigöz Corolla. O zaman hayran kalmıştım Toyota'ya. Ara sıra kullandırırdı bana. Daha sonra göreve başlayınca ev arkadaşımda Corolla ekip arabası vardl, hayranlığım o dönemde daha da arttı. Ayrica Derindere sahibi Ömer Amcanın da katkısı yok değil. Să̆ olsun bana çok yardımı oldu. Öğrencilik yıllarımda ve dügünümde. Evlendikten sonra ilk arabamı aldım dizel Auristi. 2011'de de sifir dizel Corolla Elegant aldım. Zannedersem bir daha da vazgeçemicem.

Özellikle küçük yaşlarda görülen ve beğenilen otomobillerin bir hedef haline gelebildiği görülmektedir. Küçük yaşlarda hedef olarak belirlenen otomobillerin gelecekte alındığında bağl1lık yarattığ 1 ve vazgeçilemediği, geçmişteki anıların da etkisiyle olumlu tutumlar yarattığını söylemek mümkündür. $\mathrm{Bu}$ açıdan geçmiş ve anılarda saklı otomobillere ve markalara karşı, rahatlıkla duygusal bağ geliştirilebildiği görülmüştür. Kullanıc1-136'nın yorumları bu durumu göstermektedir.

Kullanıc1-136 (2012): 1996 yilında orta okula giderken bir arkadaşımın babası sifir petrol yeşili 1.6 xei almıştı. O yillarda sanırım fiyatı 2 milyar civarıydl, kendisi o dönemde 15-16 yaşlarındayd, beni okula almaya geliyordu, ben arka koltukta patron edastyla oturuken arka koltuktan beri gözüm o ön kolsoldaydı hep. Çok hoş görünüyordu derken, ileride bir gün mutlaka almalıyım dedim ve 2004 Eylül'de 1999 model 1.6 Terra ile Toyota'cı olduk, şu an 2011 1.33 Corolla bende 2011 Avensis Elagant Extra ailemde var. Bu ikisini almadan önce çok araba araştırdık ama Toyota'dan başka bir araca ısınamadık açıkçası.

Kullanıc1-136'nın yorumundaki gibi, tüketicilerin geçmişi ve geçmişteki anıları nasıl kodladıkları görüldüğünde bu boyutun olumlu tutumlar yaratılması noktasında rolü olduğu ve bu olumlu tutumların aynı markayı tekrar satın almaya yol açabildiği görülmektedir.

\subsubsection{Emek Verilip Alınan Otomobiller}

Otomobilin insan hayatındaki büyük harcamalardan biri olması ve Türk toplumunun otomobil ile olan duygusal ilişkisi düşünüldüğünde (Güneş, 2012) kullanıcılar tarafından emek verilip kendi imkânlarıyla aldıkları otomobillerin yeri her zaman ayrı olacaktır. Halk arasındaki "emek vermeden kazanılan şeylerin gözden çıkarılması kolay olur" gibi bir anlayışın otomobiller ve markaları açısından da geçerli olduğu görülmektedir. Hayran sayfasındaki anlayış, paranın emek verilerek zor kazanıldığ ve o parayla alınacak otomobilin emek verilerek alınmış olacağından kıymetinin farklı olacağı düşüncesini yansıtmaktadır. Konuyla ilgili hayran sayfasında babasına ait olan Toyota marka otomobilini bir türlü sevemediğini söyleyen genç kullanıcıya yönelik yapılan yorumlar dikkat çekmiştir.

Kullanıc1-42 (2011): Ilerde inşallah kendi araban olunca onu seversin kardeş. Bak bende 1993 Model Toyota var kendi aracım ve ben ona aşı̆̆ım... 


\subsection{Ekonomik Faktörler}

Otomotiv sektöründe tüketicilerin tercihlerinde dolayısıyla marka bağlllığında rol alan birçok faktör vardır. Türkiye'de otomobil satın alma vergilerinin, yürütme maliyetlerinin yüksekliği gibi durumlar ekonomik faktörleri önemli kılmaktadır. Ayrıca hayran sayfası incelenen Toyota markasının daha çok B ve C segment otomobilleri ile ön plana çıkarak orta gelir grubuna hitap etmesi de (OtoHaber Dergisi, 2000: 23'den aktaran Bayraktar, 2004) tüketicilerin ekonomik faktörlere daha çok dikkat edeceğini göstermektedir. Bu doğrultuda hayran sayfasında öne çıkan marka bağl1lı̆̆ yaratabilecek ekonomik faktörler fiyat ve fiyat/performans oranı ve ikinci el avantajıdır. Bişkin'in (2004) Türkiye'de otomotiv sektörü üzerine yaptığı araştırmada kesin satın alma kararına da etki ettiği görülen bu boyutların özellikle tekrar satın alma davranışına yol açması açısından önemli olduğu düşünülmektedir.

\subsubsection{Fiyat ve Fiyat-Performans Oranı}

Fiyat birçok sektörde olduğu gibi otomobil sektöründe de önemlidir. Temel olarak satın alma davranışını etkileyen ve birçok araştırmada kesin satın alma kararına etki eden en güçlü faktörlerden olan fiyat boyutu (Arslan, 2003; Bişkin, 2004) marka bağ l1llğ1 yaratabilecek bir etmen olarak karşımıza çıkmaktadır. Davranışsal bir marka bağlılığı yaratması açısından, otomobil gibi insan hayatındaki en büyük harcama kalemlerinden birinde, fiyat boyutunun rolü azımsanamayacak durumdadır. Bu noktada özellikle bir markaya bağlılık yaratılması için öncelikle o markanın en az bir kere tercih edilmesi, ilk olması gibi durumların sağlanması için markanın tüketicilere, hitap ettiği gelir grubuna göre rekabetçi bir fiyat sunması önemli olacaktır. $\mathrm{Bu}$ şekilde düşünülmesinin sebebi birçok tüketicinin ilk etapta fiyata bakmasıdır. Örneğin:

Kullanıc1-39 (2009): Öncelikle fiyat gelir benim için. Dışarıdan baktı̆̆ında aynı model aynı özellikte iki araba var diyelim. Biri 15 lira biri 12 lira. Direkt 12 lira olana kayar gözüm...

Hayran sayfasında fiyat boyutu değerlendirilirken Türkiye'de en çok orta gelir grubuna otomobil satıldığı ve Toyota markasının da bu gelir grubuna hitap ettiği unutulmamalıdır. Ayrıca Otomobil Yetkili Satıcıları Derneği'nin (2013) yaptığı çalışmada otomobil satın alırken tüketicilerin yüzde 52'sinin taşıt kredisi aldığı ve otomobil satın alımını en çok kampanyaların etkilediği gibi sonuçlar Türkiye'deki otomotiv sektörü müşterileri için fiyat boyutunun önemini göstermektedir. Kullanıc1-40 durumu şu şekilde özetlemiştir:

Kullanıc1-40 (2009): Önce bütçeye bakacaksın ona göre araba bulup karşılastıracaksın hangisi daha cazip kaliteli olursa onu alacaksın kardeş...

Tüketicilerin değerlendirmelerine bakıldığında fiyat/performans oranının da ön plana çıktığı görülmektedir. Özellikle aynı fiyat grubundaki markaların fiyatlarıyla mukayese edildiğinde, tüketicilere fark yaratacak düzeyde faydalar sunması gerekmektedir. $\mathrm{Bu}$ gibi faydalar tüketicilerin satın alma davranışlarını etkileyerek tekrar aynı markayı tercih etmesine neden olabilmektedir.

Kullanıc1-111 (2015): Toyota'dan sonra imkânlar elveriyorsa tabii ki Mercedes. Değilse Toyota forever...

\subsection{2. İkinci El Avantajı}

Hayran sayfasındaki kullanıcılar için otomobillerin ikinci elde değer kaybetmemesinin önemli olduğu görülmüştür. Araştırmanın yapıldığı Toyota markasının hayran sayfasının, çoğunlukla orta gelir grubuna otomobiller satan bir markanın (OTOshops, 20 Mart 2019) hayran 
sayfası olmasının bu durumda rolü vardır. İkinci el performansına söz konusu markanın sorunsuzluk, sağlamlık ve dayanıklılık gibi boyutlarının da yol açtığı görülmekte, bu açıdan bu boyutlar ikinci el performansı üzerinde rol oynamaktadır.

\section{Kullanıc1-142 (2012): Toyota'dan şaşma ne zaman satarsan sat zarar etmezsin.}

Kullanıc1-142 "ne zaman satarsan sat zarar etmezsin" şeklindeki yorumuyla, Toyota'nın ikici elde sağladığı avantajlar sayesinde tercih edilmesi gerektiğini "Toyota'dan şaşma" ifadeleriyle belirtmiştir. Kullanıcının kendi tavsiyelerine paralel bir şekilde davranacağı düşünüldüğünde ikinci el faktörü vasıtasıyla markaya davranışsal açıdan bağlandığını söylemek mümkündür. Ayrıca Kullanıc1-142'nin yorumu kesin satın alma noktasında ikinci el performansının markaları her daim bir adım önde tutacağını, ikinci el performansı iyi olan bir markadan zarar edilmesinin söz konusu olmadığını göstermektedir. Bu açıdan Bişkin'in (2004) ortaya koyduğu, ikinci el değerinin kesin satın alma kararına etkisini de destekler niteliktedir.

Otomobillerin ikinci elde değer kaybetmemesi ve rahat satılması gibi ikinci el avantajları hayran sayfasındaki kullanıcılar tarafından önemsenmekte ve marka tercihi ve akabinde oluşabilecek marka bağlılığında rol alabilmektedir. Bu bağlamda özellikle davranışsal bir bağlılık oluşturmada rolü olacak olan markanın ikinci el performansının, markayı tekrar tercih etmenin yanı sıra sağlayacağ 1 ekonomik tatminle olumlu tutumlar da oluşturduğu görülmüştür. Ayrıca sorunsuz, sağlam ve dayanıklı otomobillerin ikinci el satışlarında avantaj sağlayacağı düşünüldüğünde bu boyutların dolaylı bir şekilde ikinci el boyutu ve ikinci el performansı sonucu oluşacak memnuniyet boyutu üzerinde de rolü olduğu söylenebilir.

\subsection{Memnuniyet}

Ar’a (2007) göre marka bağlılığı tüketicinin memnuniyet göstergesi olarak satın aldığ 1 ürünü tekrar satın almasıdır. Literatürde memnuniyetin marka bağlılığı yaratma konusunda hem zayıf hem de etkili olduğunu gösteren araştırmalar mevcuttur. Otomotiv sektörü açısından Dowling ve Uncles (1997) otomotiv sanayisinde, $\% 85$ ve $\% 95$ arasında bir oranda müşteri memnun olduğunu ifade ederken bunların $\% 60$ veya \%70'inin farklı bir markaya geçtiğini ifade etmiş̧ir. Buna karşın otomobil markaları üzerine yapılan araştırmada otomobilden kaynaklanan memnuniyetin marka sadakatini olumlu etkilediği de tespit edilmiştir (Bloemer ve Lemmink, 1992).

Memnuniyet tüketim deneyimine ait yapılan değerlendirme ve yargının sonucudur (Selnes, 1993: 30'den aktaran Eren ve Erge, 2012). Bu doğrultuda otomotiv sektörü için memnuniyet; kullanım deneyimine ait değerlendirme ve yargıların sonucu olarak tanımlanabilir. Hayran sayfasında, markaya özgü niteliklerin ve ekonomik faktörlerin, gerçek deneyimlere dayanarak memnuniyet boyutu üzerinde rolü olduğu ve memnuniyet oluşturduğu görülebilmektedir. Bu boyutların dışında hayran sayfasındaki memnuniyet, müşteri hizmetleri kapsamındaki durumlar sonucu da oluşmaktadır. $\mathrm{Bu}$ doğrultuda tüketicilerin memnuniyet kavramını daha çok satış sonrası destek, bayi ve servislerin performansı, yetkili satıcının performansı gibi müşteri hizmetleri kapsamındaki konularda değerlendirdiği görülmüştür.

\subsubsection{Müşsteri Hizmetleri}

Müşteri hizmetleri hayran sayfasındaki kullanıcıların değerlendirmeleri dâhilinde; satış öncesinde yetkili satıcı ve bayi ile başlayan ve satış sonrasında da yetkili servis, satış sonrası destekler gibi konuları içerecek şekilde devam eden hizmetlerin bütünüdür. "Neden Toyota" konu başlığı altında: 
Kullanic1-180 (2011): Herkese merhabalar ben Toyota'yl savunmuyorum. 2011 model araçta iki kere yolda kaldım ancak ikisinde de ilkinde evime yakındı aracım çekildi evime bırakıldım ikincisinde İstanbul'da bozuldu bu sefer araç çekildi geçici araç tahsis edilidi bir hafta sonra İstanbul'dan Silivriye araç kapıma getirildi kendi araçları alındl. Hiçbir ücret ödemeden bu kadar hizmet her marka sanmiyorum müsterisine böyle davransin. Kabul ediyorum bende ilk bozulduğunda çok kızdım bu arabaya nasıl güvenip yola çıkarım diye şimdi aracamı değil servise güveniyorum ve kesinlikle bir sonraki seçimim gene Toyota. Şimdi siz söyleyin böyle bir hizmet görünce insan fanatikleşmez mi?

Tüketiciler olumsuz bir durumla karş1laşsa dahi hızlı ve etkin bir çözüm sunulduğunda, olumsuz bir iz bırakmak yerine Kullanıc1-180 gibi olumlu bir tutum oluşturabilmekte ve kendi ifadesiyle fanatikleşebilmektedir. Bu açıdan markaların müşterilerine sağlayacağı satış sonrası destekler tekrar tercih edilme noktasında markalara avantaj sağlayacaktır. Ayrıca Kullanıcı180'in geliştirdiği olumlu tutum ve markayı tekrar tercih edeceğini belirtmesi, Bloemer ve Lemmink'in (1992) otomobil markasına üzerine yaptıkları çalışmada servis hizmetlerinden kaynaklanan memnuniyetin, marka sadakati oluşturabileceği düşüncesini desteklemektedir. Memnuniyetin özellikle davranışsal bağl1lık açısından bir başka deyişle tekrar satın alma noktasında değişken olduğu ve yetersiz kalabildiği görülmüştür (Dowling ve Uncles, 1997; Mittal ve Kamakura, 2001). Ancak Kullanıc1-180'in müşteri hizmetlerinden kaynaklanan bir memnuniyet sonucu, markayı tekrar satın alacağını belirtmesinin yanı sıra tutumsal açıdan da markaya karşı fanatikleştiğini ifade ederek olumlu tutumlar geliştirmesinin, gerçek bir marka bağl1lığı olarak değerlendirilebileceği düşünülmektedir.

\section{SONUÇ VE TARTIŞMA}

$\mathrm{Bu}$ araştırmada, sanal bir marka topluluğu olan Toyota Türkiye hayran topluluğu üyelerinin yazılı metin halindeki duygu, düşünce ve yorumlarını içeren mesajlar, netnografi yöntemiyle araştırılmış, Türkiye'de otomotiv sektörü açısından marka bağlılığı fenomeni hakkında çıkarımlar yapılması hedeflenmiştir. Araştırma sonucunda otomotiv sektöründe marka bağl1lığının hangi etmenlere bağlı olarak oluşabileceği ortaya koyulmuş ve bu etmenler davranışsal marka bağl1lığ ve tutumsal marka bağlılı̆̆

Araştırma Türkiye'de otomotiv sektöründe marka bağlılığı fenomenin keşfedilmesi amacıyla, netnografi yöntemiyle yapılan ilk araştırma olma niteliğini taşımaktadır. Çalışmada farklı sektörlerde ve otomotiv sektöründe yapılan marka bağl1lı̆̆ genişleten nitelikte sonuçlar elde edilmiştir. Ayrıca araştırmanın Türkiye'de otomotiv sektöründe faaliyet gösteren markalar açısından faydalı olabilecek sonuçlar sağladığı düşünülmektedir.

Araştırma sonucunda otomotiv sektöründe marka bağlılığ1 oluşturabilecek 6 ana örüntü tespit edilmiştir. Bunlar: menşe ülke etkisi, markaya özgü nitelikler, uzun süreli kullanım, duygusal bağll11k, ekonomik faktörler ve memnuniyettir. Bu örüntüler alt boyutlarıyla birlikte kapsamlı bir şekilde incelenmiştir.

Menşe ülke etkisinin marka bağlılı̆g yaratmada doğrudan ve dolaylı rolü olduğu görülmüştür. Türkiye pazarında Japonya ve Almanya ülkelerinin menşe imajlarının otomotiv sektöründeki kullanıcılarda yarattığ genel anlayışların, markaların tekrar tercih edilmesine bir başka deyişle davranışsal bağlılığa yol açabildiği görülmüştür. Menşe ülke imajından etkilenen tüketicilerin tercih ettikleri markada, menşe imajını doğrular nitelikte özellikler bulması tüketicilerde markaya karşı güven oluşmasına ve memnuniyet sağlanmasına neden olmakta, menşe ülke etkisi dolaylı olarak bu boyutlar üzerinden de marka bağ lılığına katkı sağlamaktadır. Ayrıca bu boyutların olumlu tutumlara da yol açtığı ve tutumsal marka bağlılığı yaratma noktasında da rolü olduğu görülmüştür. Hayran sayfasında görülen, Japon ve Alman markalarının tüketicilerde menşe etkisi yaratması durumu, konuyla ilgili araştırmalar yapan ve 
bu ülkelerin elektronik ve otomobil endüstrilerinde yarattığ (Brodowsky vd. , 2004; Verlegh ve Steenkamp, 1999) araştırmacıları doğrular niteliktedir.

Hayran sayfasındaki yorumlarda, Japon markalarının menşe ülke imaj1 ve gerçek deneyimlere dayanarak bazı boyutlarla özdeşleştiği görülmüş, bunlar markaya özgü nitelikler altında marka bağlılı̆̆ açısından irdelenmiştir. Markaya özgü niteliklerin doğrudan ve dolaylı olarak marka bağl1lı̆̆ 1 yaratmada rolü olduğu tespit edilmiştir. Markaya özgü niteliklerin doğrudan bir markanın tercih edilmesinde rolü olabildiği gibi, memnuniyet, güven gibi boyutlar üzerinde de rol alarak dolaylı bir şekilde marka bağlılı̆̆ına katkı yapabilmektedir. Ayrıca markaya özgü nitelikler; sorunsuzluk, sağlamlık ve dayanıklılığın uzun süreli kullanıma yol açtı̆̆ 1 ve uzun süreli kullanım boyutu üzerinden de marka bağl1lı̆̆na dolaylı katk1 yaptı̆̆ 1 görülmüştür. Markaya özgü niteliklerin altında sorunsuzluk, sağlamlık ve dayanıklılık, güvenlik, kalite ve güven alt boyutları incelenmiştir. Bu boyutların her birinin hem davranışsal hem de tutumsal marka bağlılığına yol açabileceği görülmüştür. Markaya özgü niteliklerin, Toyota markası bağlamında ikinci el boyutu üzerinde de rolü olduğu, ikinci elde tüketicilerin elini güçlendirildiği, hayran sayfasında da bu ilişkilerin kurulduğu ve dolayısıyla ikinci el boyutunu üzerindeki rolü vasıtasıyla da marka bağlılı̆̆ını dolaylı olarak etkilediği söylenebilir.

Kalite boyutunun marka bağl1lığ1 yaratmada rolü olduğu görülmüştür. Bu açıdan araştırma sonucunun, Vigripat ve Chan'ın (2007) otomotiv sektöründe yaptıkları araştırmada, kalitenin marka bağlılığına olumlu etkisi olduğu sonucu ile benzerlik gösterdiği söylenebilir. Ayrıca kalite boyutunun Ar (2007: 85-86) ile örtüşecek şekilde tüketiciye güven sağladığı tespit edilmiştir.

Güven boyutunun marka bağl1lığ1 yaratmada rolü olduğu görülmüştür. Bu sonuç literatürde marka güveni olarak ele alınan ve marka güveninin marka bağlllığına olumlu etkisi olduğunu saptayan çalışmaların sonuçlarına benzer niteliktedir (Morgan ve Hunt, 1994; Sirdeshmukh, 2002). Ayrıca Bişkin'in (2004) Türkiye'de otomotiv sektöründe yaptı̆̆ 1 araştırmanın sonuçlarına benzer şekilde güvenin kesin satın alma kararına etki ettiği, güven boyutunun tekrar satın alma üzerindeki rolü vasıtasıyla desteklenmiştir.

Aaker (1991) marka bağlılı̆̆1 konusunda, uzun süreli ilişkilerin saptanabilir başka desteklere ihtiyaç olmadan güçlü bir etki yaratabileceğini ifade etmiştir. Araştırma sonucunda benzer şekilde, uzun süre aynı marka otomobili kullanmanın marka bağlılığı yaratmada rolü olduğu görülmüştür. Otomobile ve dolayısıyla markasına bağlanma noktasında doğrudan rolü olan uzun süreli kullanım, aynı zamanda yarattığı alışkanlık ve duygusal bağ vasıtasıyla da dolaylı olarak marka bağlılı̆̆ üzerinde rol almaktadır. Daha çok tutumsal bağl1lık yaratma noktasında rolü olan uzun süreli kullanımın, bu olumlu tutumlar sonucu tekrar eden satın alma davranışına da yol açarak gerçek bir marka bağlılığ oluşturabildiği görülmüş̧ür. Hayran sayfasındaki kullanıcıların uzun süreli kullanım sonucunda duygusal bağlar geliştirdiği ve uzun süreli kullanım ile duygusal bağlar geliştirme arasında bir ilişki olduğu saptanmıştır.

Güneş (2012) otomobilin Türk toplumunda duygusal bir nesne olarak görülerek işlevinin çok ötesine geçebildiğini ifade etmektedir. Araştırma sonucunda Türk kullanıcıların benzer şekilde, çeşitli yollarla duygusal bağlılık oluşturabildiği ve bu bağların marka bağlılığı yaratmak açısından rolü olabileceği görülmüştür. Bu açıdan sonuçlar, literatürde marka duygusu olarak ele alınan ve markayla ilgili genel olarak tüm duygusal değerlendirmeler olarak tanımlanan (Matzler vd. , 2008) kavramla benzer niteliktedir ve duygusal bağlılığın gerçek marka bağlılığının önemli belirleyicilerinden olduğu görülmektedir (Chaudhuri ve Holbrook, 2001).

Türk kullanıcılarda ilklere karşı bir bağ görüldüğü, bu bağın otomotiv sektöründe de oluştuğu görülmüştür. Kullanıcıların ilk otomobillerinin markalarına karşı farklı bir bağ oluşturduğu, bu bağın olumlu tutumlar ve marka bağl1lı̆g yaratma noktasında rolü olabildiği görülmüştür. Ayrıca Toyota markası bağlamında bir kez Toyota markası kullanılmasının da 
tüketicilerde farklı izler bırakacağına, bağımlılık haline geleceğine inanıldığı hayran sayfasında görülmüştür. Bu durum literatürde marka deneyimi olarak adlandırılan kavramın duygusal bir sonucu olarak değerlendirildiğinde, Brakus ve diğerlerinin (2009) yaptığ 1 araştırmayı destekleyecek şekilde, hayran sayfasındaki kullanıcılar tarafından bir kez Toyota kullanılması olarak değerlendirilen marka deneyimi kavramının marka bağlılığı üzerinde doğrudan ve dolaylı rolü olduğu söylenebilir.

Araştırmada duygusal bağ boyutunun altında, otomobillere insana özgü nitelikler yüklenmesi ve otomobillerin aileden biri gibi görülmesi alt boyutlarına rastlanmıştır. $\mathrm{Bu}$ gibi boyutlar yine kullanıcıların rahatlıkla duygusal bağ yaratabildiğini ve bu bağların olumlu tutumlara neden olduğunu göstermiştir. Otomobillerini adeta canlı bir varlık gibi gören, tasvir eden, ailelerinden biri yerine koyan ve insanlara özgü niteliklerle anlatan kullanıcıların, otomobillerine dolayısıyla markalarına karşı bağ geliştireceği düşünülmektedir. Bu açıdan bu boyutlarında marka bağl1lığı yaratmada rolü olduğunu söylemek mümkündür.

Tüketiciler, geçmişte yaşadıkları olayları ve anıları ilkel bir şekilde hafızasında kodlamaktadır. $\mathrm{Bu}$ kodlamaların gelecekteki hedefler, hayaller haline gelebildiği veya geçmişteki efsaneler olarak hatırlanabildiği, bu gibi durumların marka bağlılığı üzerinde rolü olabileceği görülmüştür. Odabaşı'nın (2004) postmodern bireylerin geçmişle bağ kurmaktan ve onu bugüne taşımaktan haz aldığı yorumunun doğruluğu hayran sayfasında test edilmiştir. Tüketicilerin geçmişteki hikayelerini anlattıkları otomobillerin markalarını birer hedef haline getirerek gelecekte bu markaları tercih ettikleri ve bu durumun tekrar satın alma noktasında da rolü olduğu dolayısıyla hem davranış hem tutumsal açıdan gerçek bir marka bağlılığına yol açabileceği görülmüştür.

Araştırmada emek verilerek, tüketicilerin kendi imkanları dahilinde aldıkları otomobillerin markalarına karşı olumlu tutumlar geliştirdikleri, özellikle orta gelir grubunda bu durumun marka bağ lıllğı üzerinde rolü olduğu saptanmıştır.

Ekonomik faktörler marka bağl1lı̆̆ üzerinde rolü olabilecek bir diğer boyut olarak bulunmuştur. Bu noktada tüketicilerin yorumları, Türkiye'deki ekonomik şartlar, otomobil satın alma vergilendirmeleri ve otomobillerin ortalama yürütme maliyetleri gibi değişkenler göz önünde bulundurularak ve incelenen hayran sayfasının ağılıklı olarak Toyota markasının kullanıcılarından oluştuğu, Toyota'nın da orta gelir grubuna hitap eden bir marka olduğu (OtoHaber Dergisi, 2000: 23'den aktaran Bayraktar, 2004) düşünülerek yorumlanmıştır. Marka bağl1lığı üzerinde rolü olan ekonomik faktörler fiyat-fiyat/performans oranı ve ikinci el boyutu olarak oluşmuştur.

Literatürde kesin satın alma kararına etki ettiği saptanan fiyat boyutu (Arslan, 2003; Bişkin, 2004), birçok üründe olduğu gibi otomobillerde de önemlidir. Hayran sayfasında kullanıcılar fiyatı ilk baktıkları boyut olarak vurgulayabilirken, fiyat boyutunun davranışsal bir marka bağl1lığ 1 yaratmada rolü olduğu görülmüsstür. Fiyatına göre tüketiciyi tatmin edecek bir performans sunulduğunda ise olumlu tutumlar da oluşabildiği, özellikle kendi fiyat grubunda hem davranışsal hem de tutumsal bir marka bağlılığına yol açabileceği görülmüştür. Fiyat/performans oranının tüketiciyi tatmin etmesi durumunda bahsedilebilecek bir diğer nokta, fiyatın memnuniyet boyutu üzerinde rolü olduğu ve bu şekilde dolaylı yoldan da marka bağlılığına katkıda bulunduğudur.

Diğer ekonomik boyut olan ikinci el boyutu, sorunsuzluk, sağlamlık ve dayanıklılık gibi markaya özgü niteliklerin doğal bir sonucu olarak görülebilir. Nitekim hayran sayfasındaki kullanıcılar da benzer şekilde düşünmektedir. İkinci el boyutunun marka bağl1lığı üzerinde davranışsal bir rolü olduğu söylenebilir. Ayrıca ikinci el boyutu memnuniyet üzerinde de rol almakta ve marka bağl1lığına dolaylı bir katkı yapmaktadır. Özellikle orta gelir grubunun tercih edeceği bir araçta ikinci el boyutunun marka bağlılığı yaratılması açısından rolü olacağı 
görülmüştür. Bu açıdan Bişkin'in (2004) kesin satın alma kararına etki ettiğini saptadığ 1 ikinci el boyutunun, araştırmada tekrar eden satın alma davranışına yol açabildiği üzerinden desteklendiği söylenebilir.

Literatürde tartışmalı bir konu olan memnuniyet kavramının, marka bağlılığı üzerindeki rolü araştırma sonucunda ortaya koyulmuştur. Memnuniyet kavramı, hayran sayfasında ağırlıklı olarak, tatmin kavramı gibi çok boyutlu ve farklı düzeylerde, tüketicinin doğrudan ürün ve hizmet hakkındaki, satış süreciyle ilgili ve satış sonrası hizmetlerle ilgili değerlendirmeleri şeklinde ortaya çıkabilecek bir kavram olarak ele alınmıştır (Homburg ve Giering, 2001'den aktaran Özdemir ve Koçak, 2012). Bu açıdan hayran sayfasında müşteri hizmetleri kapsamında, satış öncesi ve esnasında yetkili satıcı, satış sonrası destek, yetkili bayi, yetkili servis gibi konulardaki olumlu deneyimlerin marka bağ l1lığı yaratmada rolü olduğu ve memnuniyete yol açtı̆̆ görülmüş̧ür.

Bloemer ve Lemmink'in (1992) otomotiv sektöründe yaptıkları, yetkili satıcı ve servis hizmetlerinden kaynaklı memnuniyetin marka bağl1lı̆̆ 1 üzerine olumlu etkisi olduğunu ortaya koyan araştırmayı destekleyecek şekilde yetkili bayi ve yetkili servislerin marka bağlılığı yaratmada rolü olduğu saptanmıştır. Genel olarak memnuniyet boyutunun, diğer araştırmaları doğrulayacak şekilde marka bağl1lığı üzerinde rolü olduğu görülse bile (Bloemer ve Lemmink 1992; Hallowel 1996) bu durumun tutumsal marka bağlılı̆̆ ile sınırlı kalabildiği ve tekrar eden satın alma davranışına yol açmadığı örneklere de rastlanmıştır. Bu açıdan Dowling ve Uncles'in (1997) otomotiv sektöründe memnuniyetin davranışsal bağlılık noktasında yetersiz kalabildiği sonucu da desteklenmiştir. Benzer şekilde otomobil markaları üzerine yaptığı araştırma sonucunda, memnuniyetin marka bağl1lığı üzerindeki etkisinin yaş, eğitim seviyesi, medeni durum gibi demografik değişkenlere bağlı olarak farklılaşabileceğini tespit eden Mittal ve Kamakura'nın (2001: 136) sonuçlarının doğruluğu görülmüss, memnuniyetin marka bağlılığı üzerindeki rolünün, kültürden kültüre hatta kişiden kişiye değişebilecek karmaşık bir konu olduğu saptanmıştır. Ayrıca memnuniyetin marka güveni üzerinde rolü olduğu ve bu vasitayla dolaylı olarak da marka bağlılı̆̆ üzerinde rol aldığ görülmüş, bu sonuçlar Çabuk ve Orel (2008), Eren ve Erge (2012) gibi araştırmacıların sonuçlarını desteklemiştir.

Araştırmada gerçek bir marka bağlılığı oluşması için hem davranışsal hem de tutumsal bir marka bağl11ığı oluşması gerektiği görülmüştür. Bu açıdan literatürdeki araştırmalarla benzerlik göstermektedir (Amine, 1998; Dick ve Basu, 1994; Oliver 1999; Morgan ve Hunt, 1994).

\section{6. ÖNERILER}

Araştırma sonucunda Türkiye'de otomotiv sektöründeki markalara yönelik öneriler tespit edilmiştir.

İlklere karşı oluşturan duygusal bağın, olumlu tutumlar ve marka bağlılığ yaratmadaki rolü görülmüştür. Türk toplumu gibi otomobili duygusal algılayabilen bir toplumda, ilk olan her şey gibi otomobilin de ayrı yeri olacaktır. Bu açıdan markaların ilk otomobilini alacak olan kullanıcılara uygulayacağ bir adım olduğu düşünülmektedir. Bu kapsamda, özellikle ilk otomobilini alacak görece genç kullanıcılar üzerine yapılabilecek bir çalışmanın gelecek adına marka bağlılı̆̆ 1 yaratmada rolü olabileceği düşünülmektedir. Ayrıca aynı markayı uzun süreler kullanan veya ilk markası olan kullanıcılar gibi olumlu tutumlar oluşturan kullanıcıların, markadan vazgeçme sebepleri araştırıldığı takdirde bu durumu önlemeye ve marka bağlılığı yaratmaya yönelik etkin stratejiler geliştirilebileceği düşünülmektedir. 
Araştırmada bir kez Toyota kullanılması olarak tespit edilen boyutun belli markaların bir kez kullanılması olarak düşünülmesi durumunda, özellikle araştırmada saptanan markalara özgü niteliklere benzer özellikleri taşıyan markalar için marka bağl1lığ yaratma noktasında rolü olabileceği, markaların daha önce kendi markalarını hiç kullanmamış olan kullanıcılara çeşitli kampanya veya indirimler uygulanabileceği, bu şekilde hem markayla tüketiciyi tanıştırma, hem de olumlu tutumlar yaratmak adına bir fırsat yaratılmasının faydalı olabileceği düşünülmektedir.

Toyota markasının Türkiye'de orta gelir grubuna hitap etmesinden hareketle, orta gelir grubu için ekonomik faktörlerin önemli olduğu, bu açıdan rekabetçi bir fiyatla sunulan fiyat/performans oranının davranışsal açıdan bir bağ yaratabileceği görülmüştür. Aynı segmentte bir otomobil alınacak olsa dahi, otomobillere yüksek ücretler ödenmesi, özellikle orta gelir grubunda olumlu tutumların etkisini azaltarak fayda odaklı bir tercihe yöneltebilmektedir. Bu açıdan Toyota gibi markaların, pazardaki avantajlarını sürdürmeleri açısından aynı ürün kalitesini sürdürerek, istikrarlı bir fiyat politikası izlemeleri gerektiği düşünülmektedir.

Orta gelir grubundaki kullanıcıların markalarına karşı olumlu tutumları olsa dahi daha yüksek fiyatlı, lüks segmentteki farklı markaların otomobillerini hayal edebildikleri, kendilerine hedef olarak koydukları ve imkânları el verdiği takdirde markadan vazgeçebilecekleri görülmektedir. Bu durum araştırmada incelenen Toyota markasının üst gelir grubuna hitap eden otomobillerine yatırım yapması gerektiğini göstermektedir. Ayrıca markanın bu gibi tüketicileri elde tutabilmesi için özdeşleştiği sorunsuzluk, sağlamlık ve dayanıklılık gibi boyutların yanına performans, konfor gibi boyutları da ön plana çıkacak şekilde eklemesi gerektiği düşünülmektedir.

Araştırma sonucunda müşteri hizmetlerinin ve müşteri hizmetleri sonucu oluşan memnuniyetin gerçek bir marka bağ lılığı oluşturabilecek şekilde davranışsal ve tutumsal marka bağ l1lı̆̆ 1 üzerinde rolü olduğu görülmüştür. Bu boyutta yaşanan olumsuzlukların ise markadan vazgeçmeye kadar varan durumlara yol açabildiği görülmüştür. Bu doğrultuda önem taşıyan müşteri hizmetleri kapsamındaki yetkili servis ve bayilerin tüketici memnuniyetini arttırmak konusunda eğitimlere tabi tutulabileceği, sadece problem çözme konusunda değil, müşterileri farklı şekillerde tatmin etmenin de yollarının saptanabileceği düşünülmektedir. Örneğin bir tüketicinin dile getirdiği gibi tüketicilerin doğum günleri gibi özel günlerde, tüketicilere verilebilecek hediye veya sağlanabilecek indirim, kampanyaların tüketicilerde olumlu tutumlar yaratmak adına etkili olabileceği düşünülmektedir. Bu bağlamda satış sonrası destekler otomobil markalarının unutmaması gereken bir noktadır. Marka bağl1lı̆̆ oluşturmak açısından son derece önemli görülen satış sonrası destekler sadece bir problem durumunda verilen desteklerden ibaret değildir. Satış sonrasında her daim tüketicinin söz konusu markayı tercih ettiği için memnun olması sağlanmalı, tüketicilere kampanyalar, firsatlar sunulmalı, marka ile olan ilişkisi taze tutulmalıdır. Tüketicilere söz konusu markayı tercih etmelerinden dolayı ayrıcalıklı oldukları hatırlatılmalı ve ilgi gösterilmeli, bu şekilde olumlu tutumlar sağlanmalıdır.

Yetkili servislerin tüketicilerin gözünde güvence gibi görüldüğü bu açıdan uzun vadeli ilişkilerin teminatı olduğu söylenebilir. Otomobil insan hayatındaki büyük harcamalardan biri olduğundan, otomobil konusunda problem yaşayan kullanıcıların olumsuz tutumlar oluşturması doğaldır. Ancak araştırma sonucunda bu olumsuz tutumların tüketicinin probleminin etkin bir şekilde çözülmesi sonucu eskisinden güçlü olumlu tutumlara yol açabildiği görülmüştür. Bu açıdan yetkili servislerde yetkin bir personel ağı oluşturulması ve bu servislerin düzenli olarak denetlenmesi markalara önerilmektedir. $\mathrm{Bu}$ şekilde tüketicilerin bir problem yaşamaları durumunda dahi markalar durumu avantajlarını çevirebilir ve markaya karşı sert tavırlar alınmasının, markadan vazgeçilmesinin önüne geçebilirler.

Sektörün geleceği olarak görülen güvenlik boyutuna önem verilmesi gerektiği ve sektördeki markaların ar-ge yatırımları bu alana yönlendirmeleri gerektiği, araştırma bulguları ve otomobil sektörünün geleceği üzerine yapılan diğer araştırmalar bağlamında söylenebilir. 
Yaşadığımız çağda internetin gücü ve markanın önemi, marka topluluklarını pazarlamacılar açısından önemli mecralar haline getirmiştir. Günümüzde marka toplulukları, sanal marka topluluklarına geçiş yapmakta, her şeyin dijitalleştiği bir dünyada sanal marka topluluklarının önemi giderek artmaktadır. Otomotiv sektörü gibi marka bağl1lı̆̆ yaratmanın zor olduğu, karmaşık dinamikler barındıran bir sektörde, Toyota Türkiye hayran sayfası gibi sanal otomobil marka topluluklarının da son derece önemli bir konuma geldiği görülmektedir. Bu açıdan markaların, kar amacı gütmeksizin, kendi istekleri dâhilinde marka için bir araya gelen kullanıcıların bulunduğu otomobil hayran toplulukları üzerine, sanal mecralarda etkili, keşfedici ve inovasyon odaklı araştırmalar için ideal bir yöntem olan netnografinin kullanılacağı araştırmalar yapmaları ve ar-ge yatırımlarını sanal marka toplulukları gibi geleceğin platformları üzerine yoğunlaştırmaları önerilebilir. Netnografi gibi görece az maliyetli bir yöntemle elde edilecek olan tüketici içgörülerinin otomotiv sektörü açısından karlı ve avantajlı olacağını söylemek mümkündür.

Türkçe literatürde otomotiv sektöründeki marka bağl1lığını ele alan sınırlı sayıda kaynak olduğu söylenebilir. Bu açıdan otomotiv sektöründeki marka bağlılığının irdelenmesi ve daha derin bir şekilde araştırılması, araştırmacılara tavsiye edilmektedir.

\section{SINIRLILIKLAR}

Araştırmanın sınırlılığı, çeşitli kaynaklarda netnografi yöntemine sıkça getirilen bir eleştiridir. Berg ve Lune (2015: 265) netnografi yöntemiyle geleneksel etnografiye göre sınırlar kaldırılarak benzer gruplarda bulunan ülkenin dört bir yanından topluluğa ve görüşlerine ulaşma imkânı olduğunu belirtmişlerdir. Ancak bu durumda araştırmacı fiziksel ortamda gözlemleyebileceğine kıyasla daha az miktarda çevrimiçi olarak paylaşılmış veri türüyle sınırlı kalacaktır. İnsanların yayınladıkları yorumları incelemenin, insanlara soru sormak veya onları konuşurken izlemek gibi sıradan eylemlerden bile daha az veri sunacağı kabul edildiğinde, netnografi yönteminin sağlayacağı veri açısından sınırlılığının bulunduğu söylenebilir.

\section{KAYNAKÇA}

Aaker, D. A. (1991). Managing brand equity: Capitalizing on the value of a brand name. New York: The Free Press.

Aaker, D. A. (2009). Güçlümarkalaryaratmak. çev: Erdem Demir, İstanbul: MediaCat Yayınları.

Aaker, D. A. (2009). Marka değeri yönetimi. çev: Ender Orfanlı, İstanbul: MediaCat Yayınları.

Akyüz, A. M. ve Arıtan, T. (2015). Tüketicilerin otomobil markalarına yönelik marka sadakatleri ve tercihleri üzerine bir araştırma. Uluslararası Yönetim İktisat ve İşletme Dergisi, 11(26), 195-220.

Amine, A. (1998). Consumers true brand loyalty. The Central Role of Commitment Journal of Strategic Marketing, 6(4), 305-319.

Ar, A. A. (2007). Marka ve marka stratejileri (2. basım). Ankara: Nobel Yayınları.

Arslan, K. (2003). Otomobil alımında tüketici davranışlarını etkileyen faktörler. İstanbul Ticaret Üniversitesi Dergisi, 3, 83-103.

Aurand, T. W., Gordon, G. L.ve Schoenbachler, D. D. (2004). Building brand loyalty through individual stock ownership. Journal of Product \& Brand Management, 13(7), 488-497.

Basu, K. ve Dick, A. S. (1994). Customer loyalty: Toward an integrated conceptual framework. Journal of the Academy of Marketing Science, 22(2), 99-113.

Brakus J. J., Schmitt B. H. ve Zarantonello L. (2009). Brand experience:What is it? How is it measured? Does it affect loyalty?. Journal of Marketing, 73, 52-68.

Berg, B. L. ve Lune H. (2015). Sosyal bilimlerde nitel araştırma yöntemleri (8. basım). çev: Hasan Aydın, Konya: Eğitim Yayınevi. 
Bişkin, F. (2004). Markanın pazarlama açısından önemi ve tüketici tercihleri-memnuniyeti çerçevesinde otomobil sahipleri üzerinde bir araştırma. Selçuk Üniversitesi, Sosyal Bilimler Enstitüsü, İşletme Ana Bilim Dalı, Üretim Yönetimi ve Pazarlama Bilim Dalı, Yayınlanmamış Yüksek Lisans Tezi.

Bloemer, J. M. M. ve Lemnink, G. A. M. (1992). The importance of customer satisfaction in explaining brand and dealer loyalty. Journal of Marketing Management, 8, 351- 363.

Brodowsky G. H., Tan J. Ve Meilich O. (2004). Managing country-of-origin choices: competitive advantages and opportunities. International Business Review, 13, 729-748.

Brown, G. H. (1952). Brand loyalty-fact or fiction. Advertising Age, 23, 53-55.

Cengiz, E. (2009). Tüketicilerin ürün tercihinde rol oynayan ürün menşeinin, marka, fiyat ve kalite değişkenleri açısından incelenmesi. Atatürk Üniversitesi İ̈BF Dergisi, 23(2), 155.

Chaudhuri, A. ve Holbrook, M. B. (2001). The chain of effects from brand trust and brand affect to brand performance: The role of brand loyalty. Journal of Marketing, 65(2), 81-93.

Creswell, J.W. (2016). Araştırma deseni: Nitel, nicel ve karma yöntem yaklaşımları (4. Basım). çev: Selçuk Demir, Ankara: Eğiten Yayınları.

Cunningham, S. M. (1956). Brand loyalty-what, where, how much?. Harvard Business Review, 34, 116-128.

Çabuk, S. ve Orel, F. D. (2008). Marka karakteristikleri ile marka ve üretici firmaya duyulan güven arasındaki ilişkilerinin belirlenmesi: Çukurova Üniversitesi ölçeğinde bir araştırma. Çukurova Üniversitesi Sosyal Bilimler Enstitüsü Dergisi, 1(17), 103-116.

Dowling, G. R. ve Uncles, M. (1997). Do customer loyalty programs really work?. Sloan Management Review, 38(4), 71-82.

Eren, S. ve Erge, A. (2012). Marka güveni, marka memnuniyeti ve müşteri değerinin tüketicilerin marka sadakati üzerine etkisi. Journal of Yasar University, 26(7), 4455-4482.

Ersoy, H. ve Fırat, A. (2006). Türk otomotiv sanayinde markaların tüketici tercihleri üzerine etkisi. Dokuz Eylül Üniversitesi Sosyal Bilimler Enstitüsü Dergisi, 8(1), 200-212.

Fournier, S. M. ve Yao. J. L. (1997). Reviving brand loyalty, a reconceptualization within the framework of consumer-brand relationships. International Journal of Research in Marketing, 14, 451-472.

Giering, A. ve Homburg, C. (2001). Personal characteristics as moderators of the relationship between customer relationship management efforts satisfaction and loyalty an empirical analysis. Psychology and Marketing, 18(1), 4366.

Guba, E. G. ve Lincoln, Y. S. (1994). Competing paradigms in qualitative research. In N. K. Denzin ve Y. S. Lincoln (Eds.), The handbook of qualitative research. Thousand Oaks CA: Sage.

Guba, E. G. ve Lincoln, Y.S. (1985). Establishing trustworthiness: Naturalistic inquiry. Beverly Hills Ca: Sage Publications.

Güngör, İ. ve İşler, D. B. (2005). Analitik hiyerarşi yaklaşımı ile otomobil seçimi. Sosyal Bilimler Dergisi, 1(2), 2133.

Gustafsson, A., Johnson, M. D. ve Roos, I. (2005). The effects of customer satisfaction, relationship commitment dimensions, and triggers on customer retention. Journal of Marketing, 69, 210-218.

Güneş, S. (2012). Türk toplumu ve otomobil. Süleyman Demirel Üniversitesi Fen Edebiyat Fakültesi Sosyal Bilimler Dergisi, 25, 213-230.

Jacoby, J. (1971). Brand loyalty: A conceptual definition. Proceedings of the Annual Convention of the American Psychological Association, 6(2), 655-656.

Kamakura, W. A. ve Mittal, V. (2001). Satisfaction, repurchase intent, and repurchase behavior: Investigating the moderating effect of customer characteristics. Journal of Marketing Research, 38, 131-142.

Kabiraj, S. ve Shanmugan, J. (2011). Development of a conceptual framework for brand loyalty: a EuroMediterranean perspective. Journal of Brand Management, 18(4), 285-299.

Keyner, D. B. ve Jacoby, J. (1973). Brand loyalty vs. repeat purchase behavior. Journal of Marketing Research, 10, 19. 
KPMG Türkiye (2018), Otomotiv: Sektörel Bakış. https://assets.kpmg/content/dam/kpmg/tr/pdf/2018/01/sektorel-bakis-2018-otomotiv.pdf,], Erişim tarihi: 26 Ocak 2019.

Koçak, A. ve Özdemir, M. (2012). İlişkisel pazarlama çerçevesinde marka sadakatinin oluşumu. Ankara Üniversitesi SBF Dergisi, 67(2), 127-156.

Kotler, P., Kartajaya, H. ve Setiawan, I. (2018). Pazarlama 4.0: Gelenekselden dijitale geçiş. çev: Nadir Özata, İstanbul: Optimist Yayınları.

Kozinets, R. V. (2010). Netnografi: Pazarlamacının gizli silahı: Sosyal medya anlayışı inovasyonu nasıl harekete geçirir. [Çevrim-içi: http://kozinets.net/wp-content/uploads/2012/01/netnography-turkish.pdf], Erişim tarihi: 26 Haziran 2019.

Matzler, K., Grabner-Kräuter, S. ve Bidmon, S. (2008). Risk aversion and brand loyalty: the mediating role of brand trust and brand affect. Journal of Product and Brand Management, 17(3), 154-162.

Maslow, A. H. (1943). A Theory of human motivation. Psychological Review, 50, 370-396.

Morgan, R. M. ve Hunt, S. D. (1994). The commitment-trust theory of relationship marketing. Journal of Marketing, $58,20-38$.

Muniz, A. M. ve O'Guinn, T. C. (2001). Brand community. Journal of Consumer Research, 27(4), 412-432.

Nagashima, A. (1970). A Comparison of Japanese and U.S. Attitudes Toward Foreign Products. Journal of Marketing, $34,68-74$.

Odabaş1, Y. (2004). Postmodern pazarlama. İstanbul: Kapital Medya Hizmetleri.

Oliver, R. (1999). Whence consumer loyalty. Journal of Marketing, 63, 33-44.

Otopark.com (2018). En sorunsuz 20 otomobil. [Çevrim-içi: https://otopark.com/2018/03/04/en-sorunsuz-20otomobil/], Erişim tarihi: 18 Mayıs 2019.

Parameswaran, R. ve Yaprak, A. (1987). A cross-national comparison of consumer research measures. Journal Of International Business Studies, 18, 35-49.

Patton, M. Q. (2014). Nitel araştırma ve değerlendirme yöntemleri (3.basım), çev: Selçuk Demir, Ankara: Pegem Akademi.

Romeo, J. B. ve Roth, M. S. (1992). Matching product category and country image perceptions: A framework for managing country of origin Efects. Journal of International Business Studies, 23, 477-497.

Statitsta (2019). Global car market share of the world's largest automobile OEMs in 2018. [Çevrim-içi: https://www.statista.com/statistics/316786/global-market-share-of-the-leading-automakers/], Erişim tarihi: 26 Haziran 2019.

Shim, S. ve Warrington, P. (2000). An empirical investigation of the relationship between product involvement and brand commitment. Psychology \& Marketing, 17(3), 761-782.

Steenkamp, J. B. ve Verlegh, P. W. J. (1999). A review and meta analysis of country of origin research. Journal of Economic Psychology, 20, 521-546.

Traylor, M. B. (1983). Ego involvement and brand commitment: Not necessarily the same. Journal of Consumer Marketing, 1(2), 75-79.

Türk Dil Kurumu. [Çevrim-içi: http://www.tdk.gov.tr/index.php?option=com_bts\&view=bts\&kategori1=veritbn\&kelimesec=270665], Erişim tarihi: 10 Mart 2019.

Türk Dil Kurumu. [Çevrim-içi:

http://www.tdk.gov.tr/index.php?option=com_bts\&arama=kelime\&guid=TDK.GTS.5d94e17cbcd541.17779573], Erişim tarihi :12 Mart 2019.

OTOshops (25.05.2018). Araç segmentleri-Hangi segment size göre?. [Çevrim-içi: https://www.otoshops.com/aracsegmentleri---hangi-segment-size-gore-haber-261], Erişim tarihi: 20 Mart 2019.

Vasconcellos, Eduardo A. (1997). The demand for cars in developing countries. Transportation Research Part A: Policy and Practice, 31(3), 245-258.

Varnalı, K. (2013). Dijital kabilelerin izinde: Sosyal netnografik araştırmalar. İstanbul: MediaCat Yayınları.

Varnalı, K. (2013). Dijital tutulma: Pazarlama iletişimi ve insan (2. Baskı). İstanbul: MediaCat Yayınları. 
Optimum Journal of Economics and Management Sciences, Vo1.7, No. 1- http://dergipark.gov.tr/optimum

Dalgıç and Tiltay - Brand Loyalty in the Automotive Industry: A Netnographic Research on Toyota Fan Community

Zeithaml, V. (1988). Consumer perceptions of price, quality, and value: A means end model and synthesis of the evidence. Journal of Marketing, 52(3), 2-22. 


\section{Extended Summary}

\section{Brand Loyalty in the Automotive Industry: A Netnographic Research on Toyota Fan Community}

Brand loyalty in the automotive industry: This study titled as netnographic research on Toyota Fan Community deals with the issue of brand loyalty in the automotive sector in Turkey.

The brands in the automotive sector aim to differentiate from their competitors and develop long-term relationships with consumers. Such a goal can only be achieved if a genuine brand loyalty is created and can be advantageous over competitors in the market. However, brand loyalty is a phenomenon that may occur due to complex and different factors. From this point of view, it is important for the sector and researchers to discover how consumers' brand loyalty is formed in a multidimensional sector such as the automotive sector (Vasconcellos, 1997) and one of the largest expenditures in human life.

The aim of the research in this regard is to discover how brand loyalty in the automotive industry in Turkey came to being. The study was started from the question of "How brand loyalty in the automotive industry in Turkey came to being?" and in accordance with the nature of the qualitative research and netnography method, in the research process it was focused on the questions "What are the factors that can create brand loyalty in the automotive sector? and What is the role of behavioral brand loyalty and attitude brand loyalty in the formation of brand loyalty in the automotive sector?"

Mellens et al. (1996: 512) states that brand loyalty occurs around two dimensions: behavioral and attitudinal. Behavioral brand loyalty is the result of repetitive buying behavior (Brown, 1952; Cunningham, 1956), and attitude brand loyalty is the result of positive attitudes of consumers towards the brand (Amine, 1998; Dick and Basu, 1994). In this context, in this study, consumers' re-branding, re-buying, preferring or mentioning the existence of this possibility, behavioral brand loyalty, the reasons of these behaviors, the tendencies that organize these behaviors, any positive attitude that may create emotional, desirable and cognitive dimensions are evaluated in terms of automotive brand engagement of how brand loyalty in the sector has been investigated.

The answers to the questions identified in the study, through the netnography method used to analyze online communities were tried to be found out from Turkey online fan page of the Toyota brand "www.toyotaclubtr.com" members of the online environment, were tried to be found out through opinions and thoughts they expressed in written texts. Netnography is an effective method that can explore consumption trends and consumer perceptions on digital platforms and is used in insight-oriented and innovation-oriented studies (Varnali, 2013).

www.toyotaclubtr.com which is Turkey online fan page of the selected Toyota brand was examined in the study brand loyalty phenomenon within the culture created by the community to be discovered investigated in a contextual way and the text of the user reviews, insights via analysis of brand loyalty among them. Among the comments about the brand loyalty, approximately 3000 comments were selected as the sample of the study under 5 categories that are thought to provide insight on this topic. These comments were also evaluated in the context of brand loyalty and the fan comments selected among them as a result of a detailed elimination included in the findings section.

In this study, the researcher observed the selected group for external examination for approximately 1 month. Community managers were then contacted and members of the community spent approximately 12 months in the community. Three types of data were 
collected. These are data from "www.toyotaclubtr.com" page contains all the contents of the data pool, and data without the researcher's participation, and data with the researcher's participation, generated by the e-mail interviews with the page administrators and the researcher's observations about the community created by writing.

When the related literature is examined, it is seen that there are limited number of studies focusing on certain dimensions in the automobile sector and brand loyalty in the automotive sector is not investigated in a holistic way. In this study, it is thought that the concept of brand loyalty is a variable and complex phenomenon that needs to be explored and should be explored with an inductive construct without regard to some definitions or preconceptions about certain dimensions. In this way, it is aimed to discover how brand loyalty can be created for the automotive sector in today's world where it is accepted by almost everyone that retaining existing customers is more profitable than winning new customers, and enterprises that do not have loyal customers against their brands are seen as weak and vulnerable in all aspects (Aaker, 2009). With the effect of technology, on the market where brands can offer cars with similar features at close prices and high competition prevails, to discover how long-term relationships can be created, produce innovative ideas that can create brand loyalty will also provide advice to the sector. The reason for selecting the Toyota online fan page of Toyota brand where brand fans met is because it is loaded with information in terms of brand loyalty in the automotive sector and it was thought that it would contribute to the research.

Qualitative data obtained through netnography method were analyzed through a repetitive interpretation process. The information was coded, compared, classified and made meaningful (Varnali, 2013: 32-33). The detailed qualitative analysis and interpretation process followed in the research is as follows (Berg and Lune, 2015: 383, 405; Creswell, 2016: 198; Tesch 1990):

- Determining the research question and collecting the qualitative data thought to be able to answer the research questions into a regular text,

- Reading qualitative raw data, searching the meanings under the information and developing codes in an analytical way, inductively defining the codes in the data,

- Determination of categories with the obtained codes,

- After the categories have been created, rechecking the codes, sorting out incompatibilities and reducing categories by finding comprehensive descriptive words for similar expressions or close meanings,

- Examination of the classified materials in order to separate meaningful templates and processes,

- Creating themes and patterns with decided categories,

- Presenting these themes and patterns together with the analysis of findings, showing their relations and connections with other research theories and relating them to the existing literature,

- Evaluating of analysis, findings, conclusions and recommendations within the scope of validity and reliability.

In this study, it is determined that Toyota brand users can create brand loyalty under six patterns. These are: (1) Country of origin effect, (2) Brand-specific characteristics, (3) Longterm use (4) Emotional commitment, (5) Economic factors, and (6) Satisfaction. The patterns and their sub-dimensions were evaluated in terms of behavioral brand loyalty and attitude brand loyalty. In the study, results supporting and expanding the results of previous researches have 

Araştırma

been obtained. In addition, some results which are not found in the literature available to the researcher have been determined. In addition, suggestions have been made for brands in the automotive sector. 